51

.1392

vol. 1

no. 1

NMAIREF NDIAN NOTES

D MONOGRAPHS

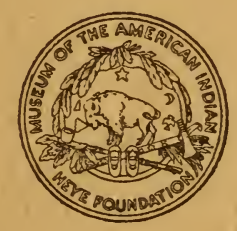

A SERIES OF PUBLICATIONS RELATING TO THE AMERICAN ABORIGINES

$$
\text { VOL. I, No. } 1
$$

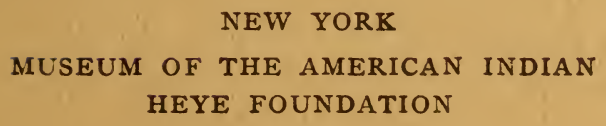

NEW YORK

MUSEUM OF THE AMERICAN INDIAN HEYE FOUNDATION

1919 
Publications of the Museum of the American Indian, Heye Foundation

THE GEORGE G. HEYE EXPEDITION CONTRIBUTIONS TO SOUTH AMERICAN ARCHEOLOGY

\section{Vol. 1}

The Antiquities of Manabi, Ecuador: A Preliminary Report. By Marshall H. Saville. 1907. $\$ 25.00$.

Vol. 2

The Antiquities of Manabi, Ecuador: Final Report. By Marshall H. Saville. I9Io. $\$ 25.00$.

CONTRIBUTIONS FROM THE MUSEUM OF THE AMERICAN INDIAN, HEYE FOUNDATION

Vol. 1

No. I: Lucayan Artifacts from the Bahamas. By Theodoor de Booy. Reprinted from Amer. Anthropol., Vol. 15, I913, No. I. 50c.

No. 2: Precolumbian Decoration of the Teeth in Ecuador, with some Account of the Occurrence of the Custom in other parts of North and South America. By Marshall H. Saville. Reprinted from Amer. Anthropol., Vol. I5, 1913, No. 3. 50c.

No. 3: Certain Kitchen-middens in Jamaica. By Theodoor de Booy. Reprinted from Amer. Anthropol., Vol. 15, 1913, No. 3. (Reprinted, I9I9.) $50 \mathrm{c}$.

No. 4: Porto Rican Elbow-stones in the Heye Museum, with discussion of similar objects elsewhere. By J. Walter Fewkes. Reprinted from Amer. Anthropol., Vol. I5, I9I3, No. 3. $50 c$. 


\section{INDIAN NOTES \\ AND MONOGRAPHS}

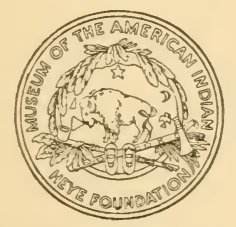

A SERIES OF PUBLICATIONS RELATING TO THE AMERICAN ABORIGINES

$$
\text { VOL. I, No. } 1
$$

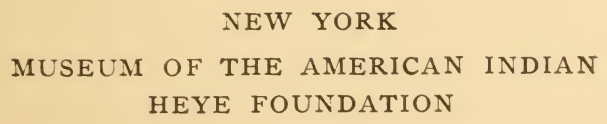





\section{ARCHEOLOGY OF THE VIRGIN ISLANDS}

BY

THEODOOR DE BOOY 



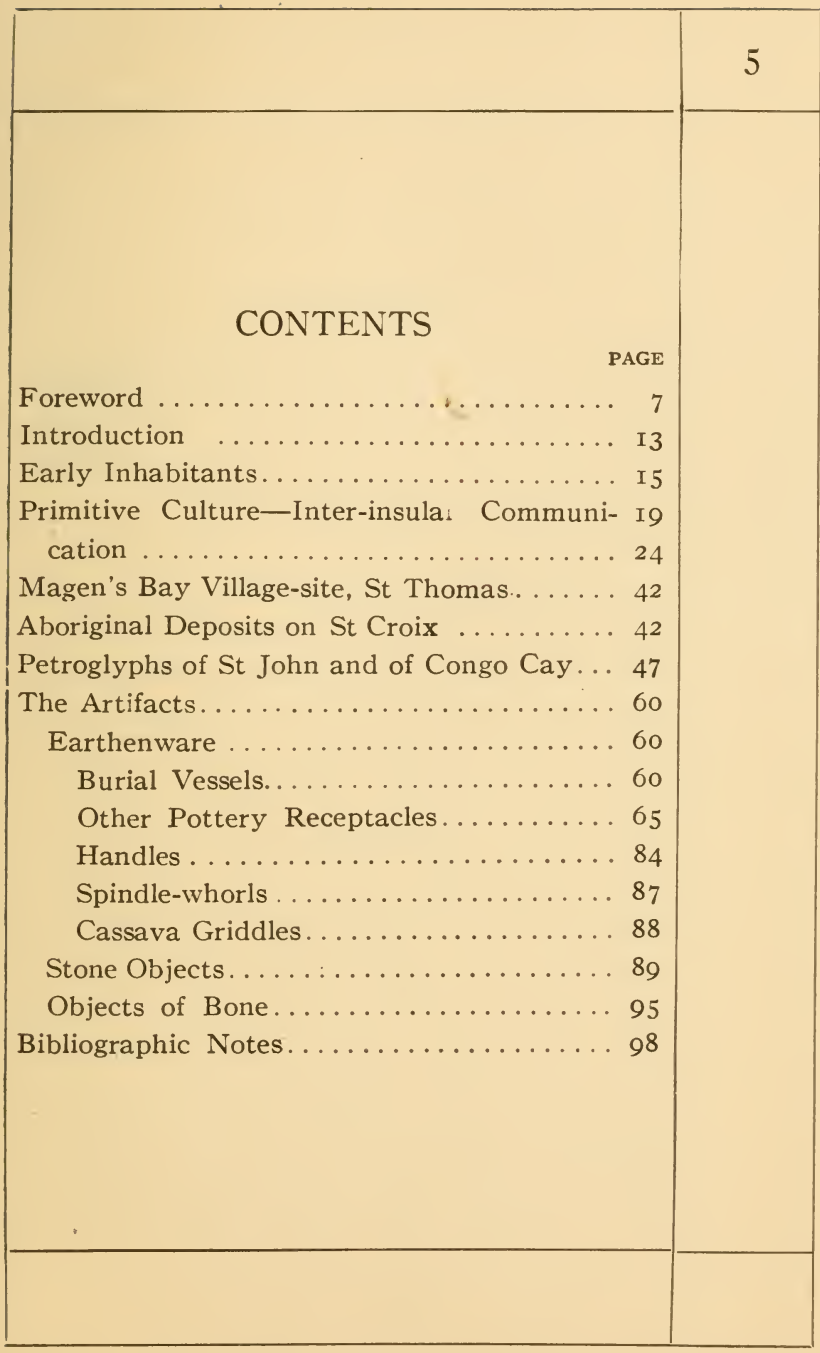





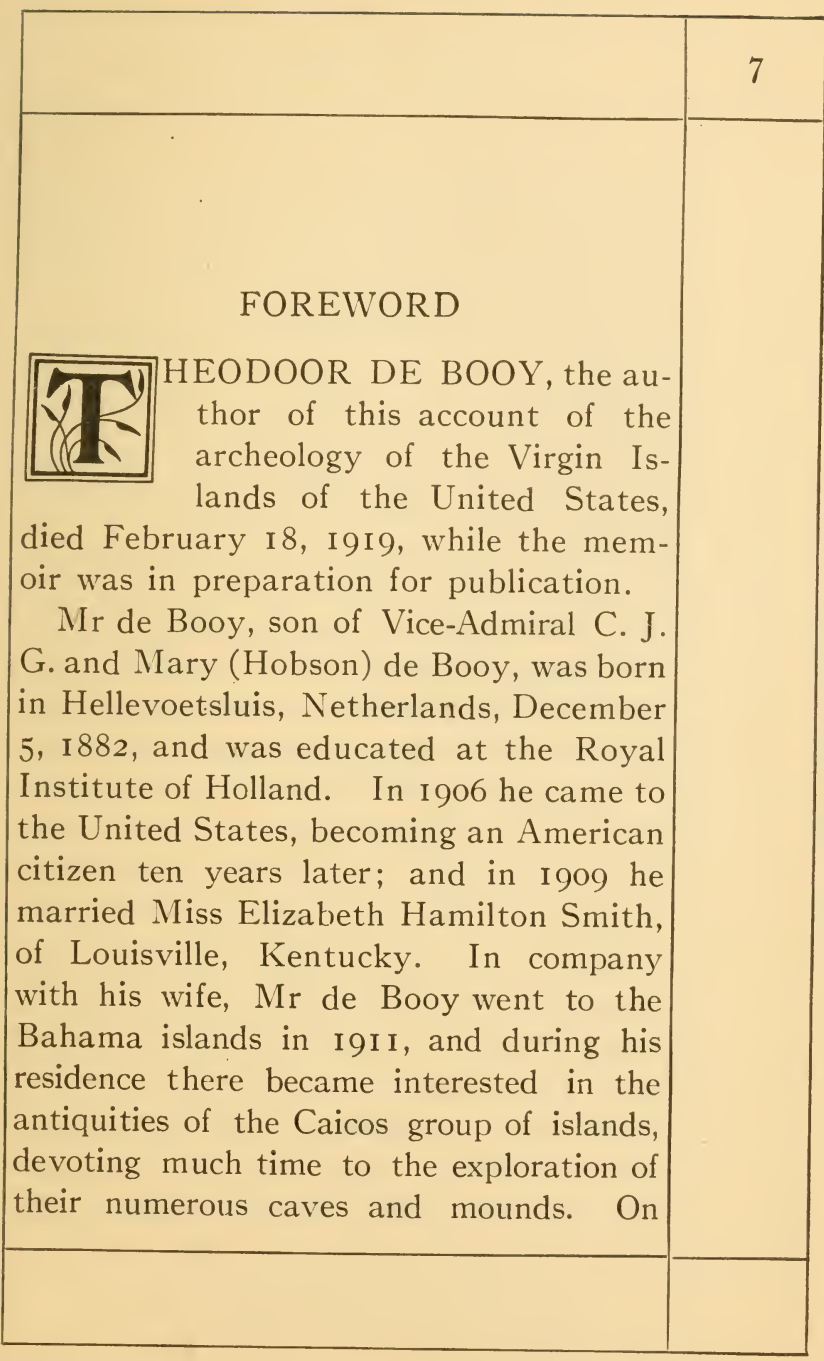




\begin{tabular}{|c|c|}
\hline 8 & VIRG I I I L A N D S \\
\hline & $\begin{array}{l}\text { his return to the United States, he pub- } \\
\text { lished, in I9I2, the first results of his ar- } \\
\text { cheological researches, in a paper entitled } \\
\text { "Lucayan Remains on the Caicos Islands." } \\
\text { He then determined to devote his life to } \\
\text { archeology, and the opportunity soon pre- } \\
\text { sented itself when he became attached to } \\
\text { the Heye Museum, now the Museum of } \\
\text { the American Indian, Heye Foundation, } \\
\text { of New York City. Mr de Booy joined } \\
\text { the staff as field explorer for West Indian } \\
\text { work, and sailed for the Bahamas in June, } \\
\text { I } 9 \text { I2, remaining there for six months. He } \\
\text { was notably successful on this trip, among } \\
\text { the most important objects recovered being } \\
\text { a remarkable paddle which he discovered } \\
\text { in a cave on Mores island. Mr de Booy's } \\
\text { next expedition was to Jamaica, where he } \\
\text { spent the months of January, February, } \\
\text { and March of I9I3, on this trip conducting } \\
\text { excavations in some of the kitchen-middens } \\
\text { found on various parts of the island. Dur- } \\
\text { ing July to October of the same year he } \\
\text { devoted his attention to Santo Domingo, } \\
\text { there undertaking the first systematic ex- } \\
\text { ploration ever made in this important and }\end{array}$ \\
\hline I & I NDIAN NOTES \\
\hline
\end{tabular}




\begin{tabular}{|l|l|}
\hline F O R E W O R D & \\
\hline little-known field, a work which was con- \\
tinued in the spring of I9I4. On his return \\
to the United States he prepared a report \\
on the results of the two expeditions, which \\
were devoted chiefly to the exploration of \\
certain caves in Santo Domingo and to \\
work on the small island of Saona. In \\
October and November of the same year he \\
made an archeological reconnoissance of \\
eastern Cuba, and was the first to discover \\
the great riches of that hitherto neglected \\
field. The year of $19 \mathrm{I} 5$ was a busy one with \\
Mr de Booy. The months of February to \\
April were spent by him in exploration and \\
excavations on the island of Margarita, \\
Venezue!a, and from May to September he \\
was occupied in excavating in the south- \\
eastern part of Trinidad. In I9I6 he made \\
a third trip to Santo Domingo, and in the \\
same year visited Porto Rico and Marti- \\
nique. On all of these islands he conducted \\
archeological researches. \\
Owing to the acquisition of the Danish \\
West Indies by the United States, Mr de \\
Booy was sent by the Museum to the \\
islands comprising this group, where he re-
\end{tabular}




\begin{tabular}{|c|c|}
\hline 10 & V I R G I ISLA N D S \\
\hline . & $\begin{array}{l}\text { mained frcm October, I9I6, until February, } \\
\text { I9i7. This was the first archeological work } \\
\text { ever done there, and he was notably suc- } \\
\text { cessful in obtaining material and informa- } \\
\text { tion respecting the antiquities of this region. } \\
\text { With this expedition his field-work for the } \\
\text { Museum came to an end. Early in I9I8 } \\
\text { he severed his connection with it, and com- } \\
\text { menced preparations for an exploration of } \\
\text { the unknown region of the Perijá mountains } \\
\text { in eastern Venezuela, and an investigation } \\
\text { of the ethnology of the Motilone Indians, } \\
\text { the savage remnant of a tribe which has } \\
\text { always kept its country free from white } \\
\text { settlement and exploration. This journey } \\
\text { was made under the auspices of the Amer- } \\
\text { ican Geographical Society and the Museum } \\
\text { of the University of Pennsylvania, of which } \\
\text { latter institution he became a field worker } \\
\text { for a short period. After his return from } \\
\text { this trip Mr de Booy joined the force of } \\
\text { the State Deparment Inquiry as one of its } \\
\text { South American experts, and was still en- } \\
\text { gaged in this work at the time of his death. } \\
\text { Mr de Booy was an able, thorough, and } \\
\text { industrious student of his chosen field of }\end{array}$ \\
\hline I & I NDIA N NOTES \\
\hline
\end{tabular}




\section{F ORE W O R D}

endeavor, and a man of attractive personality. The reports of his investigations in the West Indies, of which the present memoir is the seventh to be published by this Museum, are distinct contributions to our knowledge of the archeology of those regions. In addition he published in scientific journals numerous papers on the geography and archeology of the fields which he explored.

George G. Heye, Director. 



\begin{tabular}{|c|c|}
\hline & 13 \\
\hline $\begin{array}{l}\text { ARLANDS } \\
\text { BV THEODOOR DE Booy } \\
\text { INTRODUCTION } \\
\text { seum of the American Indian, } \\
\text { Heye Foundation, to the Vir- } \\
\text { gin Islandsof the United States } \\
\text { for the purpose of making an extended } \\
\text { archeological survey of St Thomas, St } \\
\text { John, and St Croix, the three principal } \\
\text { islands of the group. The visit to the } \\
\text { islands extended from October, I9I6, to } \\
\text { February, I9I7, during which time they } \\
\text { were still known as the Danish West In- } \\
\text { dies, as their actual transfer to the United } \\
\text { States was not made until March, I9I7. } \\
\text { Up to that date practically no pre-Co- } \\
\text { lumbian artifacts were known from St } \\
\text { Thomas or St John, excepting a small } \\
\text { number of stone celts and chisels; and }\end{array}$ & \\
\hline & \\
\hline
\end{tabular}




\begin{tabular}{|c|l|}
\hline 14 & \multicolumn{1}{|c|}{ V I R G I N I S L A N D S } \\
\hline $\begin{array}{l}\text { while St Croix had produced a quantity } \\
\text { of objects representing the material cul- } \\
\text { ture of the aborigines, these were almost } \\
\text { entirely in the hands of private collectors } \\
\text { and had not been described. } \\
\text { After a preliminary survey of St } \\
\text { Thomas, it was the good fortune of the } \\
\text { writer to discover, on the Magen's Bay } \\
\text { property of Dr P. Mortensen, King's } \\
\text { physician of the island, evidence of the } \\
\text { existence of a pre-Columbian village-site. } \\
\text { Thanks are due to Dr Mortensen for his } \\
\text { generous permission to conduct excava- } \\
\text { tions on his land for the benefit of the } \\
\text { Museum. With praiseworthy interest in } \\
\text { the scientific institutions of Denmark, } \\
\text { his native country, Dr Mortensen pre- } \\
\text { scribed only one condition to the privi- } \\
\text { leges granted, namely, that such dupli- } \\
\text { cate material as might be found be given } \\
\text { him for the National Museum at Copen- } \\
\text { hagen. The writer is likewise indebted } \\
\text { to Mr H. MacKay, a planter of the island } \\
\text { of St Croix, for permission to excavate } \\
\text { on his Salt River property. To Mr } \\
\text { MacKay may be attributed much of the }\end{array}$ \\
\hline \multicolumn{1}{|c|}{ I N D I A N N O T ES } \\
\hline
\end{tabular}





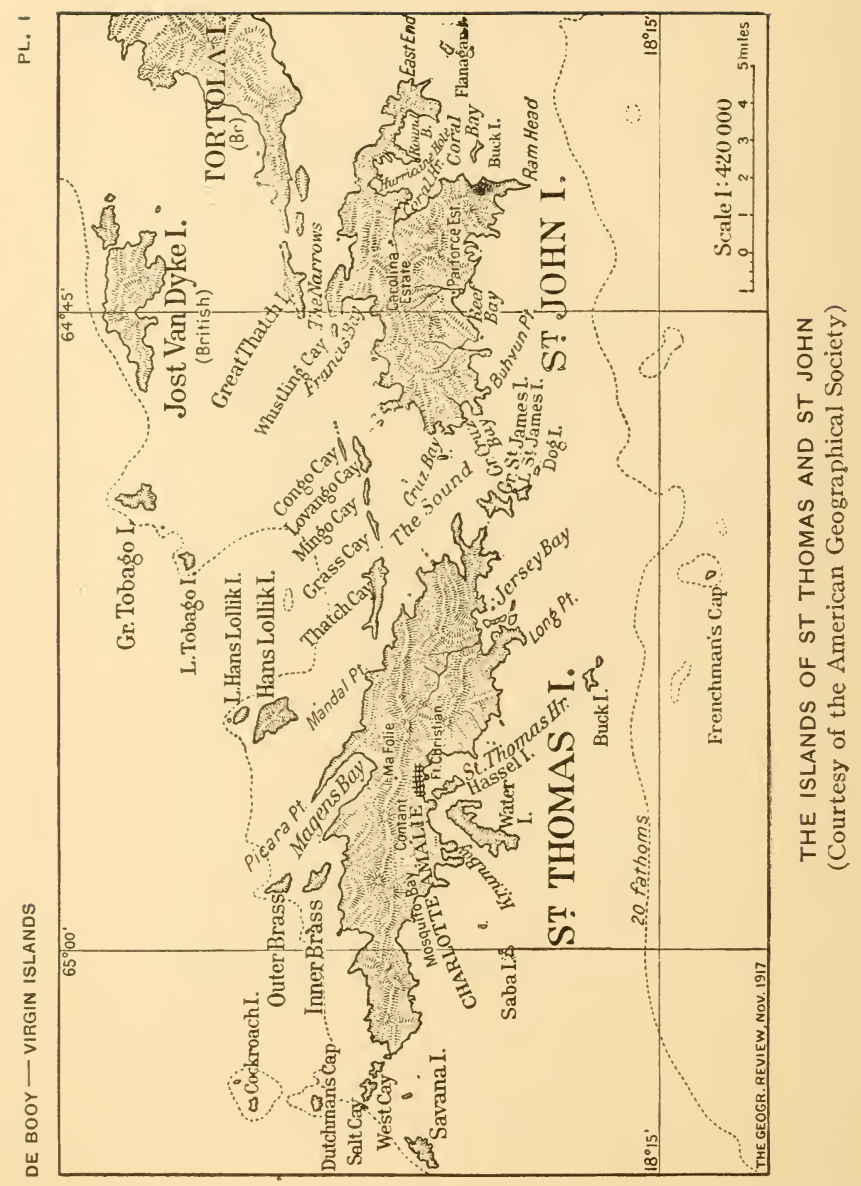




\section{EARLY IN HAB I T A N TS}

success of the undertaking on St Croix which resulted in gathering numerous artifacts illustrating its archeology. In addition to these two gentlemen, the Museum and the writer express their grateful appreciation of the aid shown them in their work by the Danish officials, who manifested active interest in the excavations and were helpful in every possible way.

\section{EARLY INHABITANTS}

In order to make this account as comprehensive as possible, it is deemed advisable first to discuss what little is known of the Indians inhabiting the Virgin Island group when the West Indies were discovered by Spanish explorers. The literature of the subject is scant, and of this a great deal cannot be taken seriously so far as archeological and ethnological data are concerned. It must be noted that the island of St Croix is not a part of the Virgin Island group proper, being separated by a passage forty miles wide.

\section{AND MONOGRAPHS}




\begin{tabular}{|c|c|}
\hline 16 & V I R G I IS L A N D S \\
\hline & $\begin{array}{l}\text { During his second voyage of discovery } \\
\text { in I } 493 \text {, Columbus reached St Croix after } \\
\text { touching at a number of the Windward } \\
\text { islands to the southward. After St } \\
\text { Croix, the Admiral discovered the group } \\
\text { of islands to the northward, naming them } \\
\text { the Virgins, in honor of St Ursula and the } \\
\text { ElevenThousand Virgins of the Catholic } \\
\text { calendar. According to the Rer. John } \\
\text { P. Knox, whose work on the history of } \\
\text { St Thomas possesses perhaps the great- } \\
\text { est merit of the few historical accounts } \\
\text { of this region, Columbus, on the report } \\
\text { of the captain of a small caravel whom } \\
\text { he had sent to explore the group, thought } \\
\text { the islands to be uninhabited. I It must } \\
\text { be noted that Knox had no ground for } \\
\text { making the statement that the islands } \\
\text { were uninhabited, as the early historian } \\
\text { from whom this author probably ob- } \\
\text { tained his reference }{ }^{2} \text { merely informs the } \\
\text { reader that, on arriving at the group, the } \\
\text { larger ships kept at high sea, owing to } \\
\text { the danger from unknown shoals and } \\
\text { rocks, while a few of the smaller vessels } \\
\text { cruised amongst the islands and recon- }\end{array}$ \\
\hline I & I NDIAN NOTES \\
\hline
\end{tabular}




\section{EARLY I N H A B I T A N TS}

noitered forty-six of them. It was in consequence of these dangers that Columbus thought it best to leave the islands and proceed to Porto Rico, whose mountains he could see from his anchorage.

The German historian Oldendorp mentions that the Indians were driven away from the Virgin Islands during the reign of Carlos V of Spain, about the year I 550, the Emperor having ordered them to be treated as enemies and exterminated. ${ }^{3}$ We cannot discover from what source Oldendorp derived this information, and are inclined to believe that he was writing of St Croix, not of the true Virgin Island group. It is much more likely that such inhabitants as may have dwelt on the Virgin Islands after the discovery were taken as slaves and made to work in the mines of Hispaniola after the labor supply of the latter island had become exhausted.

The early records unanimously agree that St Croix, called Agay by the aborigines, was occupied by warlike tribes when it was discovered, and they com-

\section{A ND MONOGRAPHS}

I. N. M., I-1. 


\begin{tabular}{|l|l|}
\hline 18 & \multicolumn{1}{|c|}{ V I R G I N I S A N D S } \\
\hline $\begin{array}{l}\text { ment on the ferocity and savagery of } \\
\text { these people. These were the tribes } \\
\text { which attempted to repel, by force of } \\
\text { arms, the soldiers sent ashore by Colum- } \\
\text { bus to explore the island. }{ }^{4} \text { It has fre- } \\
\text { quently been stated that this encounter } \\
\text { with the Indians caused the first act of } \\
\text { bloodshed in the New World between the } \\
\text { conquistadores and the aborigines. This, } \\
\text { however, is not true, as an encounter had } \\
\text { already taken place during the first voy- } \\
\text { age of Columbus, in I492, when he dis- } \\
\text { covered Samana bay of the island of His- } \\
\text { paniola; indeed this bay was named the } \\
\text { Bay of Arrows by the Admiral in com- } \\
\text { memoration of the encounter. }{ }^{5} \text { It will } \\
\text { therefore be seen that St Croix cannot } \\
\text { lay claim to the doubtful honor of having } \\
\text { been the scene of the first battle in the } \\
\text { New World. During the fight b tween } \\
\text { the natives of St Croix and the Spaniards, } \\
\text { a Galician was slain by an Indian woman, } \\
\text { and another soldier seriously wounded. } \\
\text { Peter Martyr relates that the wounds } \\
\text { were caused by the poisoned arrows used } \\
\text { by the natives, and states that the poi- }\end{array}$ \\
\hline \begin{tabular}{l} 
I N D I A N N O T E S \\
\hline
\end{tabular}
\end{tabular}




\section{EARLY I N HAB I T A N T S}

son oozed from the arrows when the points broke off. It is also of interest to note that the same historian relates that the St Croix Indians, who made the attack, appeared to be governed by the same woman who inflicted the wounds on the slain Spaniard and his companion.

There are no trustworthy records of the ultimate fate of the aboriginal inhabitants of St Thomas, St Croix, and St John, for even if Oldendorp's statement referred to is founded on fact, it does not necessarily imply that the extermination of the Indians was completely effected. Nevertheless, when the Danish, Dutch, and French settlers arrived on the islands at different periods of the seventeenth century, no Indians were found to inhabit them, and the fate of the aborigines from that time onward is completely veiled.

PRIMITIVE CULTURE - INTER-INSULAR COMMUNICATION

As has been stated, the first investigations were carried on at Magen's bay,

A N D M O O G R P H S 


\begin{tabular}{|c|c|}
\hline 20 & VIRG I N ISLANDS \\
\hline & $\begin{array}{l}\text { St Thomas. "After these, the writer made } \\
\text { a survey of the island of St John, and } \\
\text { finally of St Croix. Beyond the petro- } \\
\text { glyphs at Reef bay on St John which } \\
\text { were studied and photographed, there } \\
\text { was no evidence of prolonged Indian oc- } \\
\text { cupancy of this island. A few potsherds } \\
\text { were found on what is called "Old Oven" } \\
\text { hill on the northern coast of St John, be- } \\
\text { tween Leinster bay and Smith bay, which } \\
\text { led to the belief that this eminence had } \\
\text { at one time been occupied by the abor- } \\
\text { igines, but in any event the occupancy } \\
\text { must have been brief. However, the } \\
\text { sherds found were so small that they } \\
\text { were of little use for comparative study. } \\
\text { The St Croix site, on the other hand, } \\
\text { produced a large number of excellent } \\
\text { artifacts, and, as at Magen's bay on St } \\
\text { Thomas, extensive excavations were con- } \\
\text { ducted there. } \\
\text { The writer cannot agree with the state- } \\
\text { ment made by Dr J. Walter Fewkes that } \\
\text { "Santa Cruz [St Croix] and St Thomas } \\
\text { have cultural resemblances in their an- } \\
\text { tiquities to the Porto Rican or Jamaican }\end{array}$ \\
\hline I & I NDIAN NOTES \\
\hline
\end{tabular}




\section{INTERCOMMUNN ICATION}

area." 6 The specimens from St Croix resemble those from St Thomas so closely that one may assert that the aborigines of the two islands were of the same origin and culture. While an occasional artifact has been found on St Thomas and on St Croix that undoubtedly belongs to the Porto Rican area, the presence of a specimen of this kind, where islands are in such close proximity that their mountains loom on the horizon as landmarks for canoe travelers, could mean hardly more than that the Indians of the two islands either had intercourse with those of Porto Rico or that they waged war against the Porto Ricans and possibly carried off articles of Tainan manufacture as their spoils. Cultural resemblances, in order to be complete, must be found in pottery as well as in artifacts of stone, and no pottery object was found on either St Thomas or on St John that in any degree resembles ceramic specimens from either Porto Rico or Jamaica. While the writer personally recovered perhaps ten stone and bone objects that

\section{A N D M O N G R A P H}




\begin{tabular}{|l|l|}
\hline 22 & \multicolumn{1}{|c|}{ V I R G I N I S L A N D S } \\
\hline $\begin{array}{l}\text { had their origin in Porto Rico, if not } \\
\text { even in Santo Domingo or Jamaica, he } \\
\text { found also one potsherd on St Croix that } \\
\text { could have come only from Trinidad, it } \\
\text { having the painted red-and-white decor- } \\
\text { ation so typical of the earthenware of } \\
\text { that southern island. } \\
\text { The writer is strongly of the opinion } \\
\text { that St Croix and St Thomas were inhab- } \\
\text { ited by tribes that made extended voy- } \\
\text { ages, either for trading or for warfare, } \\
\text { practically throughout the West Indies. } \\
\text { The finding of some of the so-called "col- } \\
\text { lar-stones" proves that voyages to Porto } \\
\text { Rico were commonly undertaken, and the } \\
\text { presence of a grotesquely carved "swal- } \\
\text { lowing-stick" of bone urges connection } \\
\text { with Santo Domingo. That journeys to } \\
\text { Jamaica were possibly undertaken is sug- } \\
\text { gested by the finding, in a kitchen-midden } \\
\text { on St Croix, of a cylindrical stone pen- } \\
\text { dant, specimens of this kind being more } \\
\text { typical of Jamaican culture than of that } \\
\text { of other Antillean islands. Then again, } \\
\text { the potsherd above mentioned tends to } \\
\text { prove that some communication had been }\end{array}$ \\
\hline I N D I A N N O T ES \\
\hline
\end{tabular}




\section{INTERCOMMUNICATION}

held with either Trinidad or the northern coast of Venezuela.

It is hardly likely that the tribes inhabiting St Thomas and St Croix made such voyages for purposes of barter or of peaceful intercourse; it is far more likely that these natives undertook extended journeys like these in order to wage war against the more peaceful Arawak tribes of the other Antillean islands, and that the specimens recovered by our expedition were obtained by force of arms rather than through trade. Had the intercourse with the islands to the westward been of a peaceful nature, it is probable that the Indians would have adopted some of the technique of the potter's art from their neighbors. As it is, the pottery from St Thomas and St Croix, of which thousands of specimens were recovered, bears no resemblance to that from Jamaica, Porto Rico, Santo Domingo, and Cuba, in either form, technique, or design. Some slight resemblance may be suspected between the pottery of the islands and that of Trinidad; but this resem-

\section{A ND MONOGRAPHS}




\begin{tabular}{|c|c|}
\hline 24 & VIRGIN ISLANDS \\
\hline & $\begin{array}{l}\text { blance is so remote that it is more a ques- } \\
\text { tion of the individual opinion of the } \\
\text { writer than of tangible proof. } \\
\text { Knowing from early historians that St } \\
\text { Croix was inhabited by warlike tribes, } \\
\text { and finding that the pottery and other } \\
\text { artifacts from St Thomas bear a direct } \\
\text { resemblance to those from St Croix, it } \\
\text { may reasonably be said that the inhab- } \\
\text { itants of St Thomas were of the same } \\
\text { warlike and ferocious tribes. } \\
\text { IrAGEs's BAY viLLAGE-site, sT THoMAs } \\
\text { Crossing the mountain ridge which bi- } \\
\text { sects the island of St Thomas, one views } \\
\text { the bay called Magen's bay, or some- } \\
\text { times North Side bay, which stretches } \\
\text { rectangularly on the northern coast of } \\
\text { the island. Bordered on the eastern side } \\
\text { by Picara point, a rocky peninsula that } \\
\text { extends its enormous arm in a north- } \\
\text { westerly direction, and on the western } \\
\text { side by another, somewhat smaller, par- } \\
\text { alleling peninsula of similar formation, } \\
\text { the sloping, sandy, southern shore. of the } \\
\text { bay is sheltered from all but northerly }\end{array}$ \\
\hline I & I NDIAN NOTES \\
\hline
\end{tabular}




\section{ST THOMAS SITE}

and westerly storms (pl. I). From the hills commanding the bay a perfect view may be had of both the northern and the southern coasts of the island, and of many of the cays and passages in the waters surrounding St Thomas. The Indian lookouts in ancient times could have given ample warning of the approach of any marauding tribes and thus enable the inhabitants to seek the shelter in the forests or to prepare themselves for attack. With a perfect sandy shore eminently suitable for beaching canoes, with soil sufficient for the cultivation of cassava and other indigenous vegetables, with a sea teeming with fish and shellfood, and with an ample supply of fresh water, the existence of the aborigines of St Thomas could have been little less than ideal. That the Indians selected Magen's bay for their village-site, in preference to even more sheltered bays on the southern coast, was due probably to the fact that their principal diet consisted of sea-food and that this was more easily obtained on the northern coast. Fur-

\section{A ND MONOGRAPHS}




\begin{tabular}{|c|c|}
\hline 26 & VIRG I N ISLA N D S \\
\hline & $\begin{array}{l}\text { thermore, it was probably easier to pro- } \\
\text { cure fresh water on the northern coast } \\
\text { of the island, considering the primitive } \\
\text { appliances the Indians had at their dis- } \\
\text { posal for making wells. } \\
\text { There are today various paths leading } \\
\text { from the shores of Magen's bay to the } \\
\text { hills above. The largest of these paths, } \\
\text { called the King's Road by the inhabitants } \\
\text { of St Thomas, leads from the shores of } \\
\text { the bay along its bordering hills to the } \\
\text { eastward, toward a property now called } \\
\text { Canaan. It was on this road, at a point } \\
\text { not more than a hundred meters from } \\
\text { the sandy shore of the bay, that the writer } \\
\text { was so fortunate as to discover a small } \\
\text { mound of aboriginal origin. During the } \\
\text { first reconnoissance of the valley lying be- } \\
\text { tween the ridges that terminate in the } \\
\text { two peninsulas forming the bay, a num- } \\
\text { ber of small potsherds were found on the } \\
\text { surface. This led to a search of the } \\
\text { neighborhood for mounds and other evi- } \\
\text { dences of Indian occupancy. It should } \\
\text { here be said that the valley between the } \\
\text { two ridges is covered with small pools of }\end{array}$ \\
\hline I & I NDIAN NOTES \\
\hline
\end{tabular}




\begin{tabular}{|c|c|}
\hline ST THOMAS SITE & 27 \\
\hline $\begin{array}{l}\text { fresh water during the rainy season; it } \\
\text { is therefore likely that the Indians came } \\
\text { to these pools for their water supply and } \\
\text { that the sherds on the surface of the } \\
\text { little valley were parts of such vessels as } \\
\text { were broken while being carried to the } \\
\text { poo!s. } \\
\text { Careful search throughout the valley, } \\
\text { which is covered with bush and under- } \\
\text { growth, was finally rewarded by the dis- } \\
\text { covery of the mound above mentioned, } \\
\text { the crest of which was not more than ten } \\
\text { feet high and which merged into the slope } \\
\text { of the hill against which it lay. The } \\
\text { mound was found to be semilunar in } \\
\text { shape, with a maximum breadth of about } \\
75 \text { feet and a width of about } 30 \text { feet. Its } \\
\text { western slope was more or less bordered } \\
\text { by the King's road, whereas the eastern } \\
\text { slope, as before mentioned, was circum- } \\
\text { scribed by the contour of the hill. Exam- } \\
\text { ination of this hill showed that its sum- } \\
\text { mit had also been occupied by Indians, } \\
\text { probably as a signal station. A number } \\
\text { of small potsherds were found upon the } \\
\text { flat crest of the height, but as it is rocky }\end{array}$ & \\
\hline A ND MONOGRAPHS & 1 \\
\hline
\end{tabular}




\begin{tabular}{|c|c|}
\hline 28 & VIRGIN ISLA N D S \\
\hline & 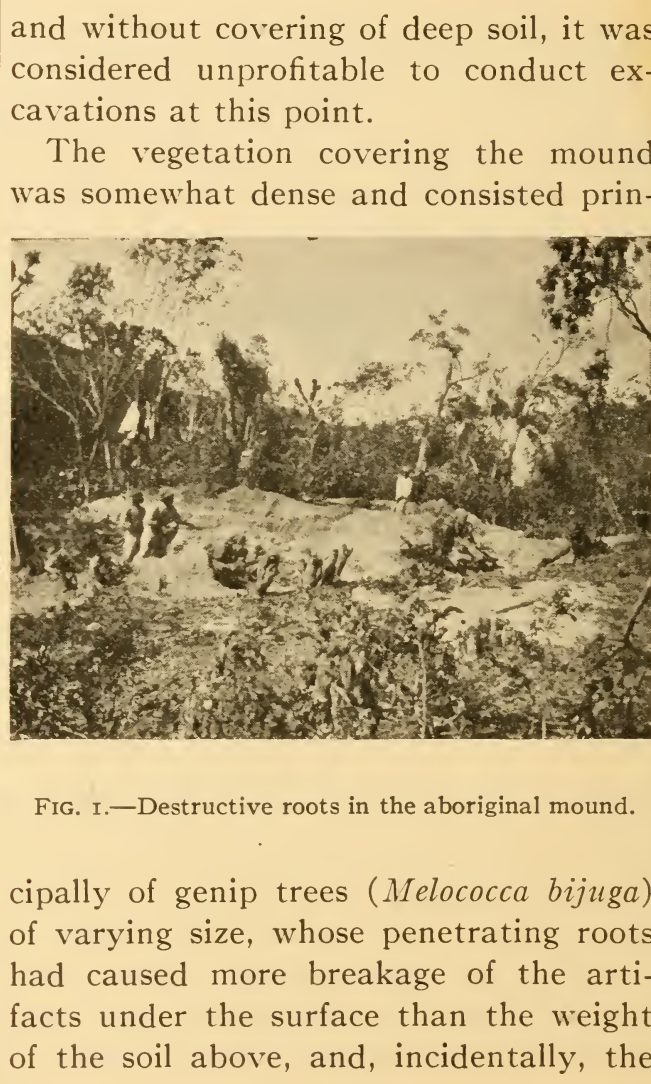 \\
\hline $\mathrm{I}$ & I N I A N NOTES \\
\hline
\end{tabular}




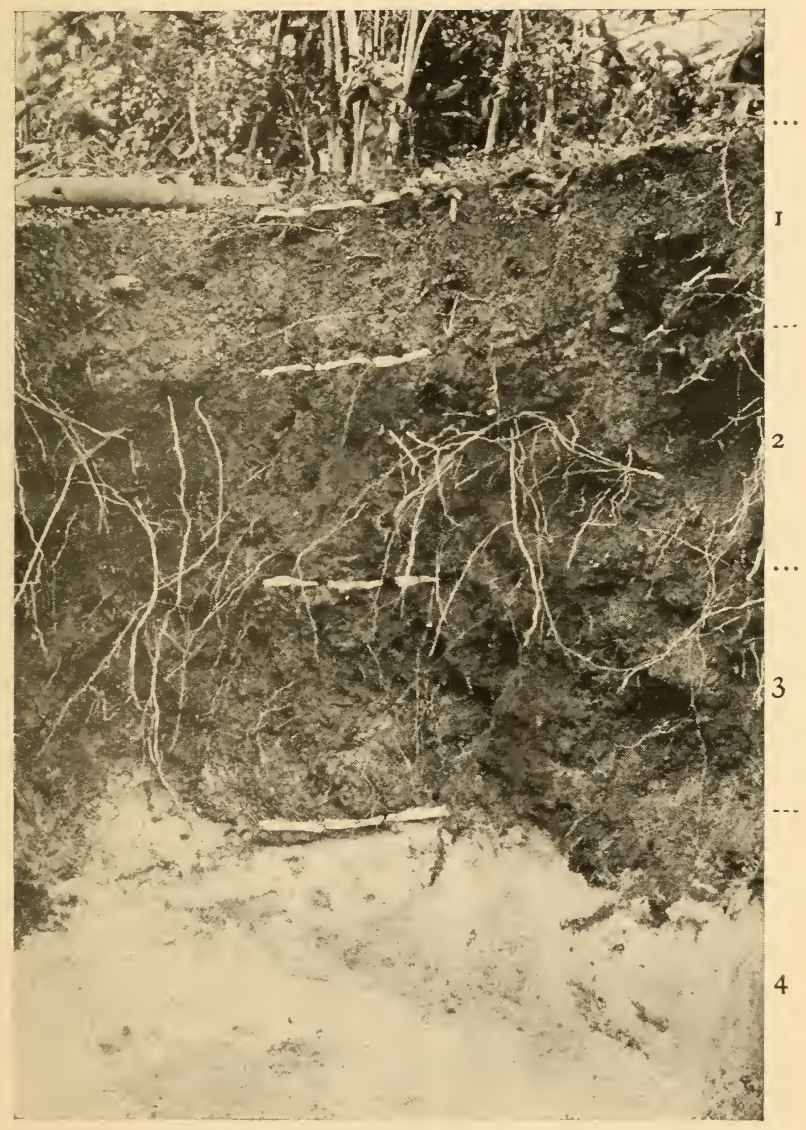

SECTION OF THE ABORIGINAL MOUND 



\section{ST THOMAS SITE}

roots made the excavation of the diluvial covering a difficult task (fig. I).

Directly beneath the diluvial deposit of the mound was found a layer of black earth, plentifully mixed with ashes, charcoal, and shells, and it was in this dark layer (pl. II) that most of the artifacts were encountered. Directly under this black stratum was found another, though not quite so dark, in which the same kind of débris was found as in the layer directly above it. The mound appeared to represent two different periods of aboriginal occupancy, although the objects found in the third layer did not differ materially in their types from those found in the second layer. But it may well be that after the formation of the lower, or third, layer, the village-șite was abandoned for a number of years, but not for such a length of time that the earth of the deposit partook of the lighter, brown, color of the diluvial deposit, yet still, long enough to have become a trifle less dark than the later deposit on top. As the illustration shows, the original

\section{A ND MONOGRAPHS}




\begin{tabular}{|c|c|}
\hline 30 & VIRG I N ISLA N D S \\
\hline & $\begin{array}{l}\text { sea-sand is found directly under the third } \\
\text { layer. By digging two feet in this lower- } \\
\text { most deposit, one reaches water, hence } \\
\text { excavations were not conducted for more } \\
\text { than a foot below the third layer. The } \\
\text { depth of the strata varied, of course, with } \\
\text { the depth of the mound. At the highest } \\
\text { part of the mound the first layer had a } \\
\text { depth of two feet, the second a depth of } \\
\text { three and a half feet, the third a depth of } \\
\text { four feet. No artifacts were found in } \\
\text { the diluvial covering, therefore we may } \\
\text { concern ourselves solely with layers } 2 \text {, } 3 \text {, } \\
\text { and } 4 \text {, the last being the sea-sand, a foot } \\
\text { to eighteen inches in depth, in which ex- } \\
\text { cavations were made. As the aboriginal } \\
\text { objects in the lower layers were not differ- } \\
\text { ent, and as the conditions under which } \\
\text { they were found were the same through- } \\
\text { out, the two layers ( } 2 \text { and } 3 \text { ) may be } \\
\text { treated as a single deposit. The illus- } \\
\text { tration (pl. II) affords the means of de- } \\
\text { termining the depth of the combined lay- } \\
\text { ers at about the highest part of the } \\
\text { mound. } \\
\text { The layer under the diluvium repre- }\end{array}$ \\
\hline I & I NDIAN NOTES \\
\hline
\end{tabular}




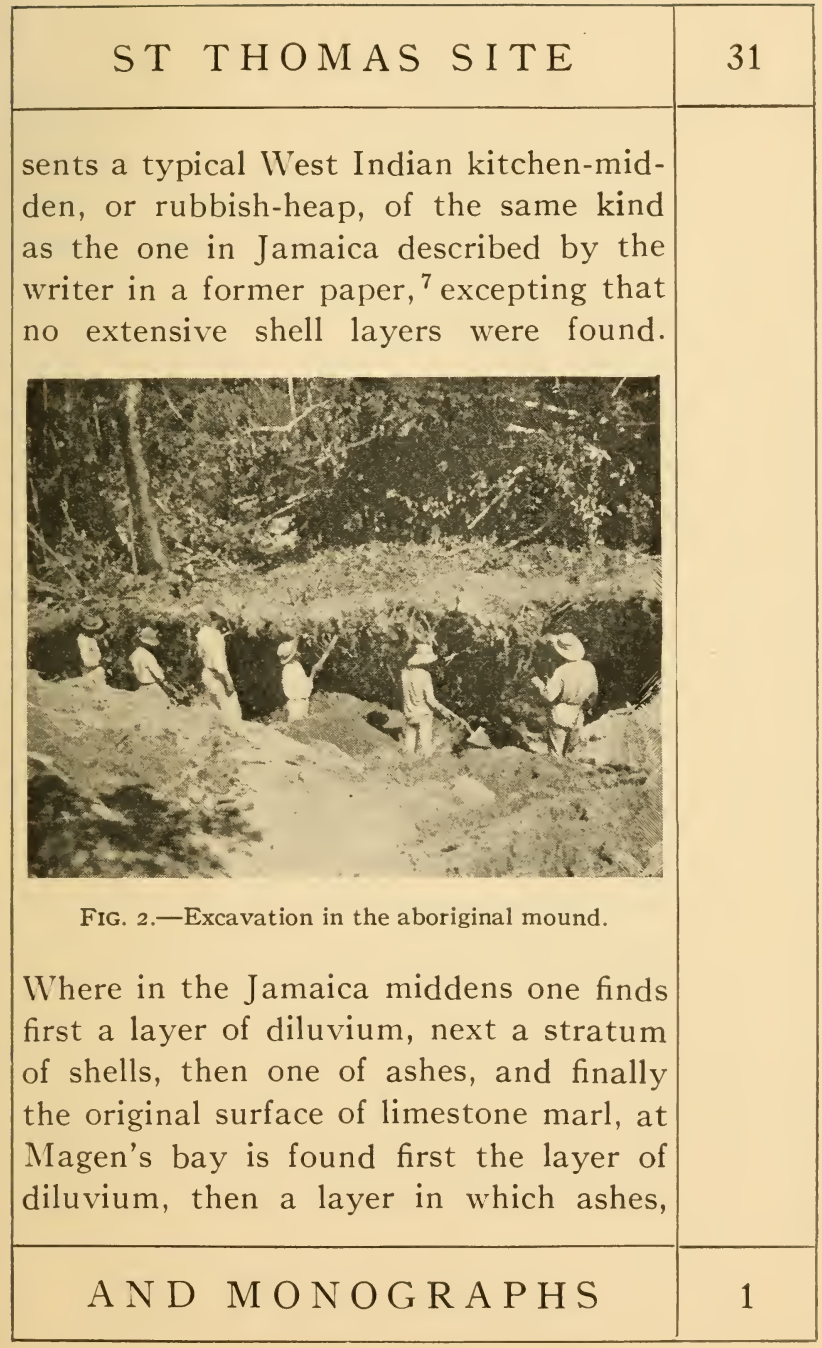




\begin{tabular}{|c|c|}
\hline 32 & VIRG I N ISLA N D S \\
\hline & $\begin{array}{l}\text { shells, and artifacts are mixed together } \\
\text { (representing in its entirety the two in- } \\
\text { tervening layers found in Jamaica), and } \\
\text { finally the original surface, in this in- } \\
\text { stance consisting of sand instead of lime- } \\
\text { stone marl. Virtually, however, there } \\
\text { is no wide difference in the middens, and } \\
\text { it is found that, except in a minor way, the } \\
\text { kitchen-middens of such other West Indian } \\
\text { islands as Cuba, Trinidad, and Santo Do- } \\
\text { mingo, as were investigated, did not vary } \\
\text { in character from those of St Thomas. } \\
\text { Close examination of the component } \\
\text { ingredients of the second and third layers } \\
\text { of the Magen's Bay deposits revealed the } \\
\text { existence of a somewhat indurated mass } \\
\text { of loam and clay, plentifully mixed with } \\
\text { ashes, charcoal, and other débris of the } \\
\text { aboriginal household. It is regretted } \\
\text { that none of the wooden artifacts were } \\
\text { preservable in the humid soil, for there } \\
\text { can be no doubt that the aborigines used } \\
\text { a large number of such, judging from } \\
\text { the accounts of early historians and from } \\
\text { the few cave specimens that have been } \\
\text { recovered from time to time. }\end{array}$ \\
\hline I & I NDIAN NOTES \\
\hline
\end{tabular}




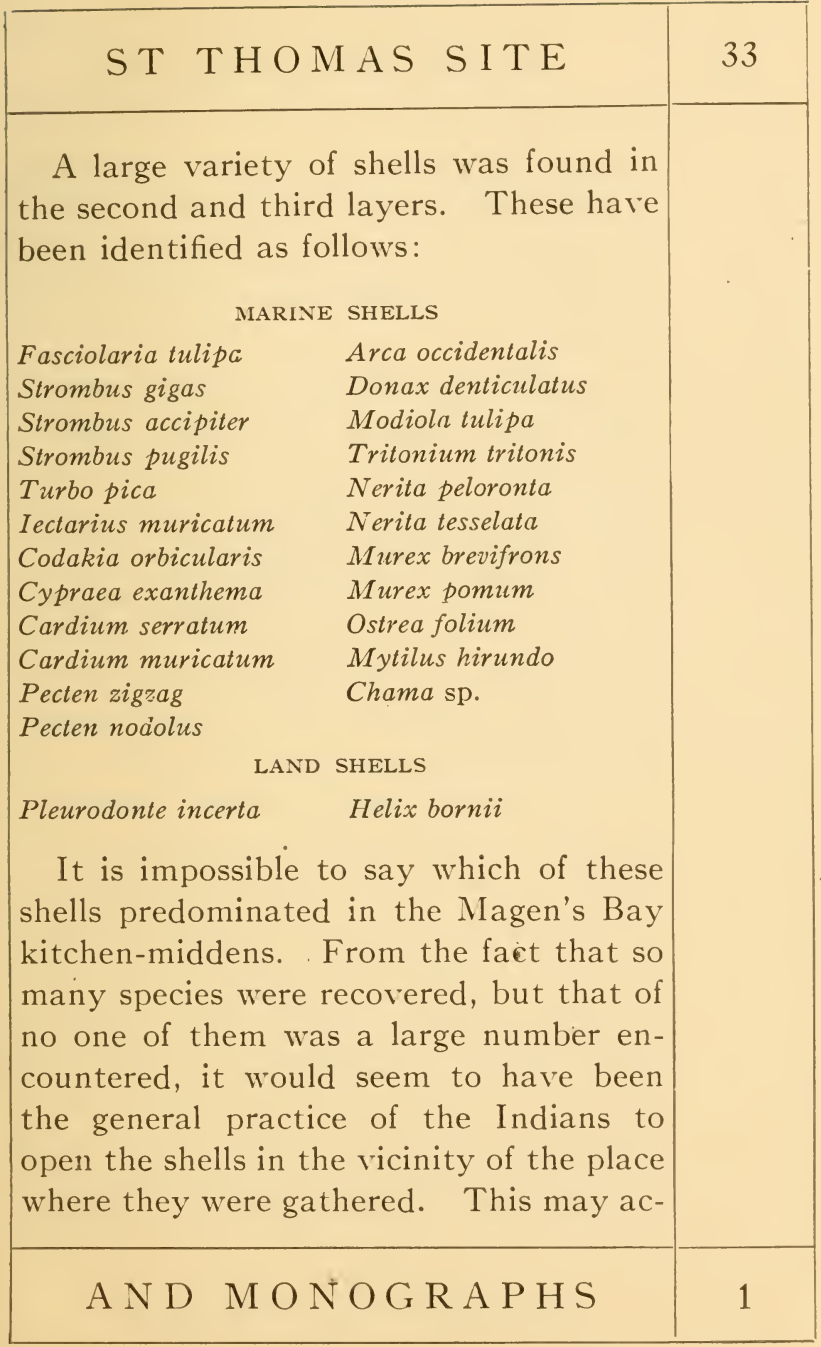

I. N. M., I-2. 


\begin{tabular}{|c|c|}
\hline 34 & V I R G I N ISLA N D S \\
\hline & $\begin{array}{l}\text { count for the fairly heavy shell-deposits } \\
\text { at Krum bay, on the southern coast of } \\
\text { St Thomas, and for the fact that in these } \\
\text { shell-deposits practically no artifacts were } \\
\text { found. } \\
\text { It should be noted that Helix bornii had } \\
\text { not been known to occur on St Thomas, } \\
\text { its nearest habitat being Porto Rico. The } \\
\text { writer found four shells of this species in } \\
\text { the Magen's Bay middens, and as all of } \\
\text { these were found together and all with } \\
\text { perforated lips, it is probable that they } \\
\text { were gathered in Porto Rico by some } \\
\text { adventurous Indian, who strung and car- } \\
\text { ried them home. } \\
\text { The writer is indebted to Dr Gerrit S. } \\
\text { Miller, Jr., }{ }^{8} \text { curator of the Division of } \\
\text { Mammals of the United States National } \\
\text { Museum, for the identification of the } \\
\text { bones of mammals and reptiles found in } \\
\text { the Magen's Bay deposits. These were } \\
\text { found to represent the following: } \\
\text { Isolobodon portoricensis Allen. Of this small } \\
\text { mammal, now extinct in the Virgin Islands and } \\
\text { Porto Rico, and not known to be living else- }\end{array}$ \\
\hline I & INDIAN NOTES \\
\hline
\end{tabular}




\section{ST THOMAS SITE}

where, 92 bones were collected on St Thomas, probabıy representing about 30 individuals.

Dasyprocta aguti (Linnaeus).

Trichechus manatus Linnaeus.

\section{REPTILES}

Cyclura mattea, new species. Three bones of a probably extinct species of large lizard (iguana) were found.

Chelonia mydas (Linnaeus). About forty fragments of shells and limbs of turtles were found. All the more complete bones appear to be those of the green turtle.

\section{BIRDS}

Mr Alexander Wetmore, ${ }^{9}$ of the United States Biological Survey, identified the bird-bones found in the kitchen-middens of Magen's bay, finding them to belong to the following:

Puffinus lherminieri Lesson. Shearwater. A Estrelata sp. Petrel.

Sula leucogastra (Boddaert). Booby.

Fregata magnificens Matthews. Man-o'-war Bird. Nyctanassa violacea (Linnaeus). Yellow-crowned Night Heron.

Gallus gallus (Linnaeus). It is a source of considerable mystification how to account for the presence of these remains of a domestic fowl

\section{A ND MONOGRAPHS}




\begin{tabular}{|c|c|}
\hline 36 & VIRG I N ISLA N D S \\
\hline & $\begin{array}{l}\text { in what undoubtedly is a pre-Columbian de- } \\
\text { posit. The only logical explanation is that } \\
\text { a rat may have carried the remains of a fowl } \\
\text { in its burrow in later days. } \\
\text { Nestrochis debooyi, new genus and species (Fam- } \\
\text { ily Rallidae). Limb bones of several individ- } \\
\text { uals of an extinct rail were found. } \\
\text { Anoïs stolidus (Linnaeus). (?). } \\
\text { Sterna sp. Possibly of Sterna anaetheta (Scopoli). } \\
\text { FisH } \\
\text { Mr Barton A. Bean, of the United } \\
\text { States National Museum, identified the } \\
\text { fish-bones in the St Thomas middens as } \\
\text { being of the following: } \\
\text { Sphyraena, Barracuda. Caranx, Crevallé. } \\
\text { Epinephelus, Grouper. Scarus, Parrot Fish. } \\
\text { Diodon, Porcupine Fish. Tylosurus, Silver Gar. } \\
\text { Balistes, Trigger Fish. Lutjanus, Snapper. } \\
\text { It will be noted that the food of the } \\
\text { aborigines of St Thomas was of consid- } \\
\text { erable variety. What with numerous } \\
\text { kinds of fish, green turtle, the Isolobodon, } \\
\text { all sorts of shell-fish, birds, and the flesh } \\
\text { of the iguana, the Indians were well sup- } \\
\text { plied with animal food. Their vege- } \\
\text { tal food probably comprised the num- }\end{array}$ \\
\hline I & I NDIAN NOTES \\
\hline
\end{tabular}




\section{ST THOMAS SITE}

erous indigenous fruits and the all-important cassava, which is such a constant adjunct to Indian life in the islands. Numerous fragments of cassava griddles, of the type .common to the West Indies, were found in the kitchen-middens of Magen's bay.

There was no evidence on St Thomas that the island had been densely populated; indeed, only two pre-Columbian sites were found on the island: the site at Magen's bay, and a very small one on the southern coast, on the shore of Krum bay, where somewhat extensive shelldeposits and an occasional sherd indicate that the place was at least visited by Indians. Of course, objects such as celts, chisels, axes, pestles, and mortars are found throughout the island, but discoveries of this kind do not indicate permanent occupancy of a particular locality.

There is no way to determine the age of the Magen's Bay deposits. As will be shown, they were covered with two feet of diluvium, but no deductions as to the age of the kitchen-middens can be drawn

\section{A N D M ONOGRAPHS}




\begin{tabular}{|c|c|}
\hline 38 & VIRG I N ISLA NDS \\
\hline • & $\begin{array}{l}\text { from this. The depth of the diluvial de- } \\
\text { posits has been found to be governed en- } \\
\text { tirely by such conditions as the nature of } \\
\text { the soil, the density of the undergrowth, } \\
\text { and the geological formation, hence one } \\
\text { frequently finds a very old deposit cov- } \\
\text { ered by only about six inches of di- } \\
\text { luvium in a region where scant vegeta- } \\
\text { tion exists, whereas a comparatively re- } \\
\text { cent aboriginal deposit, in a region with } \\
\text { a heavy rainfall and dense woods, some- } \\
\text { times is covered by four feet or more of } \\
\text { diluvium. } \\
\text { That the Magen's Bay village-site was } \\
\text { abandoned before the coming of the Span- } \\
\text { iards to the West Indies is suggested by } \\
\text { the fact that no objects of European ori- } \\
\text { gin were found. Had the tribe of which } \\
\text { the remains were found existed on St } \\
\text { Thomas during the period of the con- } \\
\text { quest of the West Indies, particularly } \\
\text { during the conquest of Porto Rico by } \\
\text { Ponce de León, it is more than probable } \\
\text { that some evidence of barter or of other } \\
\text { contact with the Spaniards would have } \\
\text { been found, such as beads, hawk-bells, }\end{array}$ \\
\hline I & I NDIAN NOTES \\
\hline
\end{tabular}




\begin{tabular}{|c|c|}
\hline $\mathrm{ST} \cdot \mathrm{THOMAS}$ S ITE & 39 \\
\hline $\begin{array}{l}\text { etc. From the condition of the skeletal } \\
\text { remains found under the kitchen-middens } \\
\text { at Magen's bay, the writer is of the } \\
\text { opinion that the site was occupied sev- } \\
\text { eral centuries before the Spanish invasion. } \\
\text { Directly beneath the second and third } \\
\text { layers of the deposits was found the sur- } \\
\text { face of sand that existed before the In- } \\
\text { dian occupancy of the site. It was in } \\
\text { this sand that nine pre-Columbian burials } \\
\text { were found-seven of adults and two of } \\
\text { children. It is far from improbable that } \\
\text { a much larger number of burials may be } \\
\text { found in the vicinity of the kitchen- } \\
\text { midden and that the remains buried in } \\
\text { the kitchen-midden itself represented but } \\
\text { a small number of the inhabitants of the } \\
\text { village-site. With three exceptions the } \\
\text { burials were accompanied with at least } \\
\text { one pottery vessel. } \\
\text { We quote the following from Dr Fewkes } \\
\text { regarding burial customs in the Lesser } \\
\text { Antilles: } \\
\text { "As skeletons sometimes occur in these sites, } \\
\text { reference to burial customs may be mentioned } \\
\text { here. The ancient Antilleans buried their dead }\end{array}$ & \\
\hline A ND MONOGRAPHS & 1 \\
\hline
\end{tabular}




\begin{tabular}{|c|c|}
\hline 40 & VIRGIN ISLA NDS \\
\hline & $\begin{array}{l}\text { in a contracted (embryonic) posture, often in the } \\
\text { floors of the houses. . . It was customary to } \\
\text { deposit mortuary offerings in the graves, which } \\
\text { accounts for the pottery and other objects found } \\
\text { by the author in the Balliceaux cemetery." 10 } \\
\text { Two burials were found by our expe- } \\
\text { dition in the Magen's Bay middens in } \\
\text { which the bodies had been interred in a } \\
\text { recumbent position, but the remains of } \\
\text { the other seven burials had been placed } \\
\text { in an embryonic posture, and after the } \\
\text { dissolution of the flesh, the skeletons. } \\
\text { were found to have become a confused } \\
\text { mass. The mortuary vessels were found } \\
\text { close to the skeletons, but in no prede- } \\
\text { termined position. IVith five of the nine } \\
\text { burials but one vessel was found; one } \\
\text { burial was accompanied with three ves- } \\
\text { sels, while three burials had no vessels } \\
\text { whatsoever. It may be mentioned that } \\
\text { no axes, amulets, or other artifacts save } \\
\text { those of earthenware were found in the } \\
\text { graves. Five of the burials were sur- } \\
\text { rounded with conch-shells (Strombus } \\
\text { gigas), which in each case seem to have } \\
\text { been placed in a circle around the body. }\end{array}$ \\
\hline I & I NDIAN NOTES \\
\hline
\end{tabular}




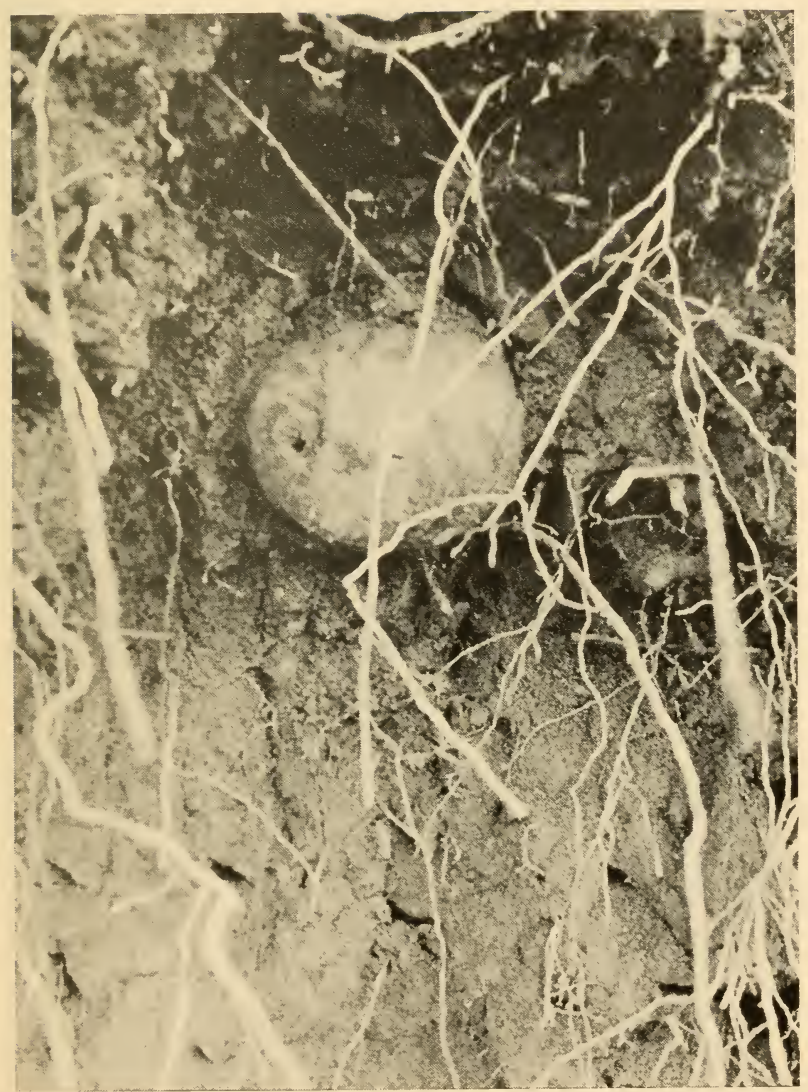

SKULL IN SITU IN ABORIGINAL MOUND 



\section{ST THOMAS SITE}

It is worthy of mention that the burials appeared to be very old, and that the bones in consequence were so brittle and in such bad condition that their preservation was not possible. Two skulls, one of an adult and one of a child, were sufficiently hard to enable preservation, and of these the child's skull was sent to the National Museum in Copenhagen.

Two of the burials were found in the layer directly above the sand, and these appeared as if deposited at a date latef than those found below the third layer. These two skeletons were in especially bad condition, owing to the moisture in the black earth and to the roots of the genip trees (pl. III). From the fact that the burials in the original sandy surface (the fourth layer) were covered and surrounded with more or less kitchen-midden débris, such as potsherds and ashes, and with black loam, etc., which evidently came from the upper layers, it is apparent that the burials were made after the occupancy of the village-site and that graves were dug in the site itself and

\section{A N D MONOGRAPHS}




\begin{tabular}{|c|c|}
\hline 42 & VIRG I N ISLANDS \\
\hline & $\begin{array}{l}\text { filled with the surrounding soil and ref- } \\
\text { use. } \\
\text { ABORIGINAL DEPosirs on sT CRoIx } \\
\text { The kitchen-middens at Salt river, on } \\
\text { the island of St Croix, did not differ } \\
\text { materially from the one at Magen's bay } \\
\text { on St Thomas (pl. Iv). Salt river in real- } \\
\text { ity is more of a sea inlet than a river, and } \\
\text { its water is salty and not potable. The } \\
\text { mouth of the inlet is bordered by an ex- } \\
\text { tensive reef, with two channels, making } \\
\text { an ideal shelter for the canoes of the } \\
\text { natives. Furthermore, the fishing on the } \\
\text { confines of this reef is said to be excel- } \\
\text { lent, and there is no reason to believe } \\
\text { that it may have been otherwise in } \\
\text { aboriginal times. In addition, the man- } \\
\text { grove trees with which the inlet is bor- } \\
\text { dered are covered with the typical man- } \\
\text { grove oysters (Ostrea virginica), and the } \\
\text { waters north of Salt river abound in } \\
\text { conchs (Strombus gigas). } \\
\text { The village-site at Salt river was far } \\
\text { more extensive than the Magen's Bay } \\
\text { site, and there is every evidence that St }\end{array}$ \\
\hline I & I NDIAN NOTES \\
\hline
\end{tabular}





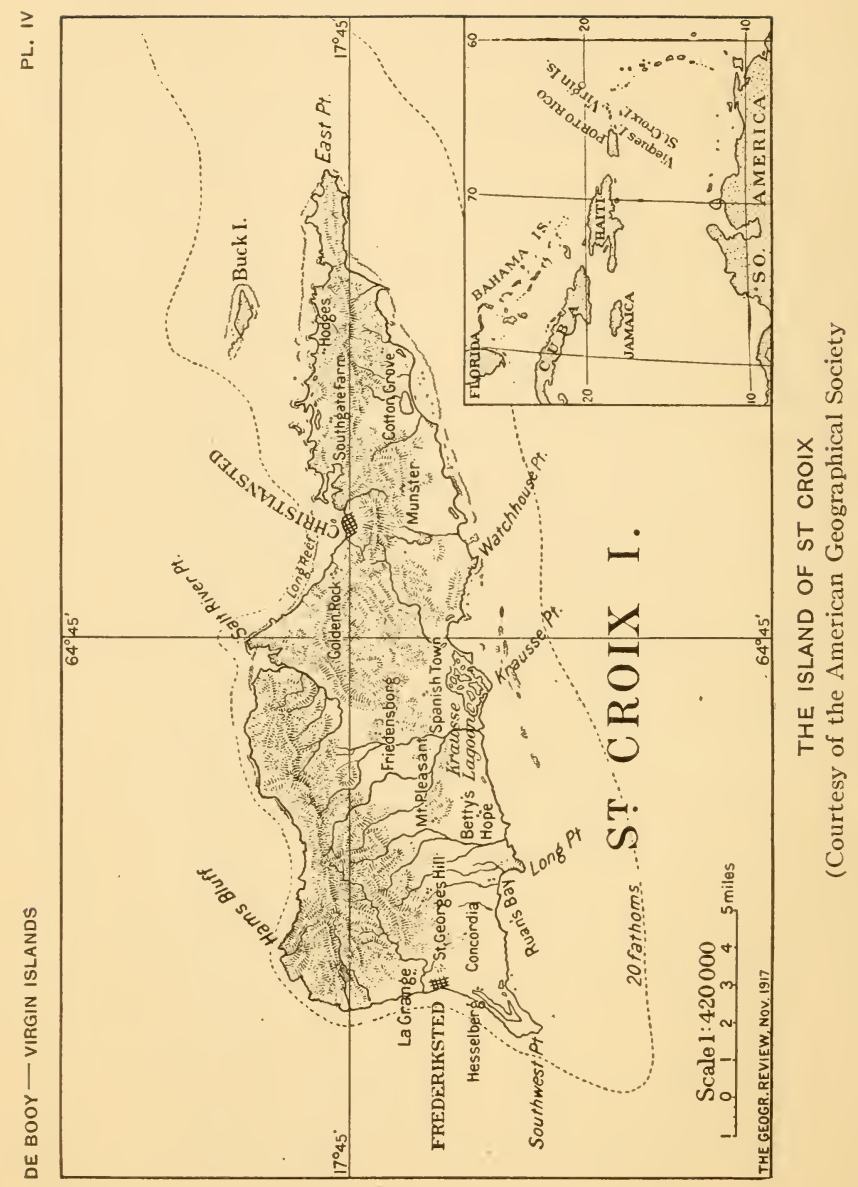




\section{ST CROIX SITE}

Croix supported a far larger pre-Columbian population than did the island of St Thomas. The deposits are found in a semicircle around a small hill on the western bank of Salt river, at the mouth of the inlet, as well as on its crest. Some practically effaced ruins on the hilltop, and the remains of a foundation for a flag-pole, indicate that in post-Columbian times the hill may have been used for a battery.

The deposits are found as far as the edge of the sea and extend thence around the hill to the bank of Salt river. In many places the kitchen-middens are of inconsiderable depth. The excavations were made in a ridge about $24 \mathrm{ft}$. wide, $120 \mathrm{ft}$. long, and $5 \mathrm{ft}$. in height, with sloping sides, extending north and south from the edge of the sea. A cross-section of this ridge shows a diluvial deposit from a foot to two and a half feet in thickness. Directly beneath this was a layer, two and a half feet thick, of the usual charcoal, ashes, potsherds, and stone objects, forming a compact mass

\section{A ND MONOGRAPHS}




\begin{tabular}{|c|c|}
\hline 44 & VIR G I I L A N D S. \\
\hline & 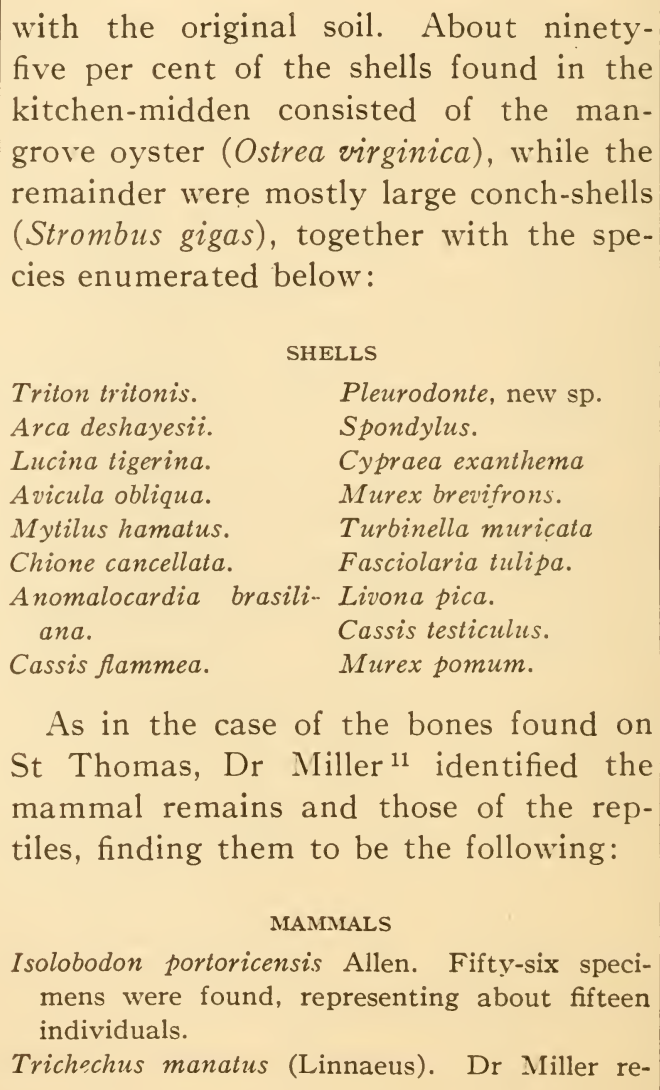 \\
\hline $\mathrm{I}$ & I NDIAN NOTES \\
\hline
\end{tabular}




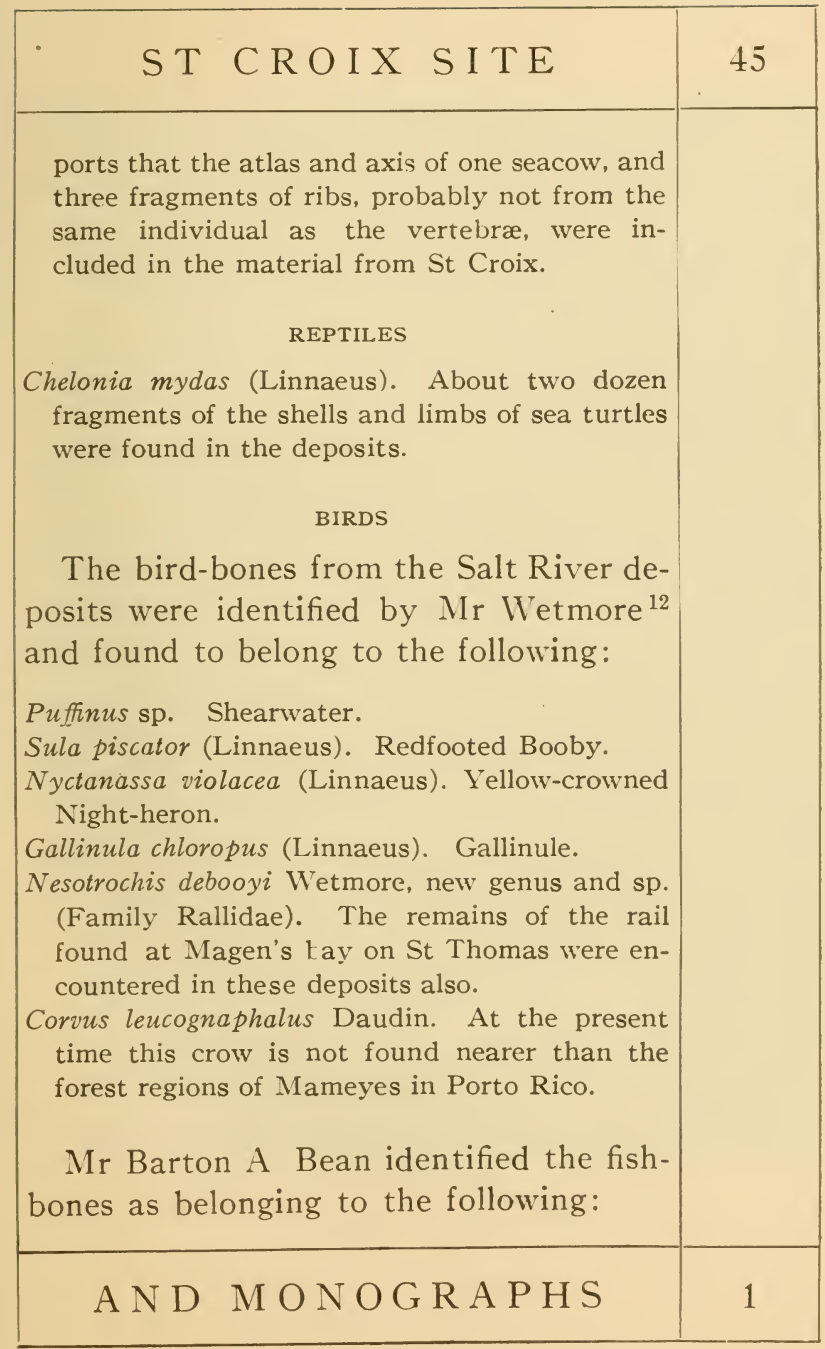




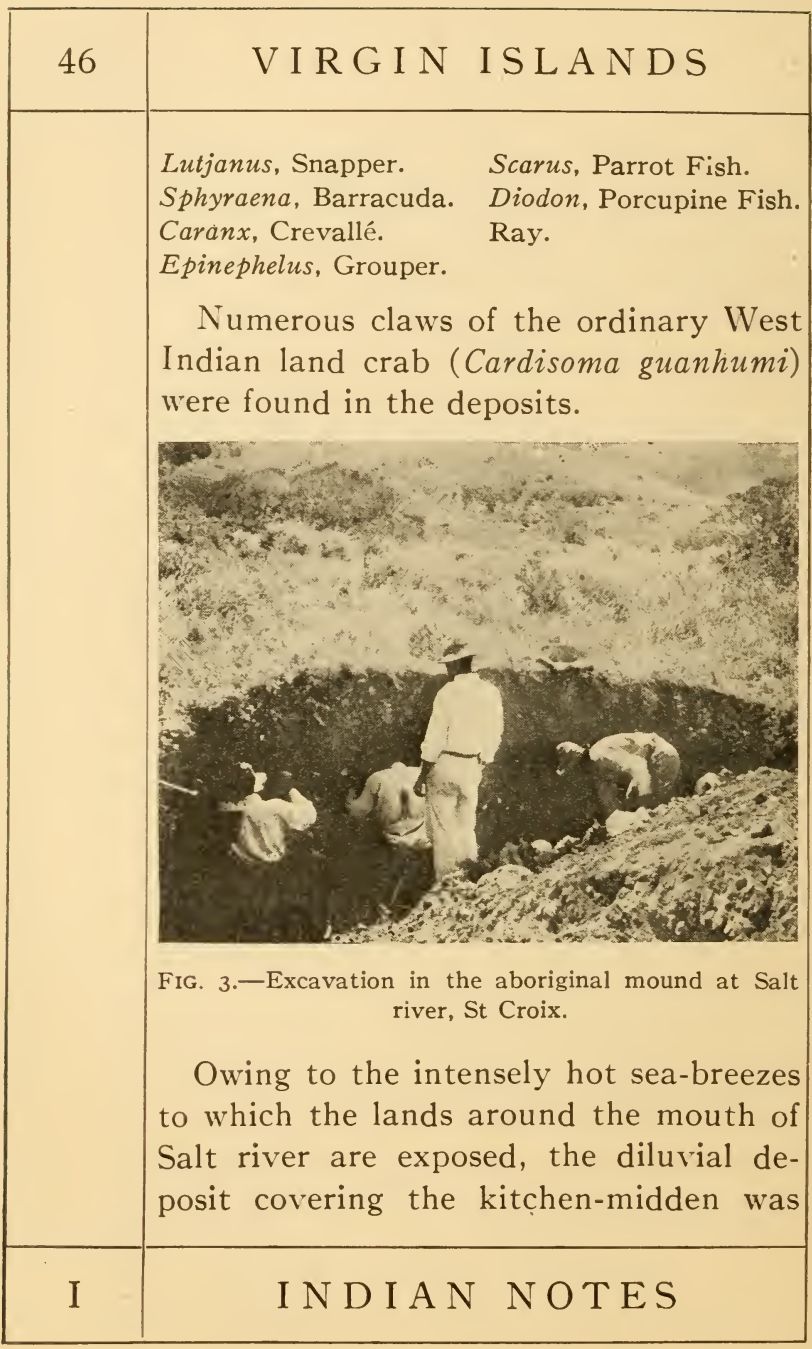




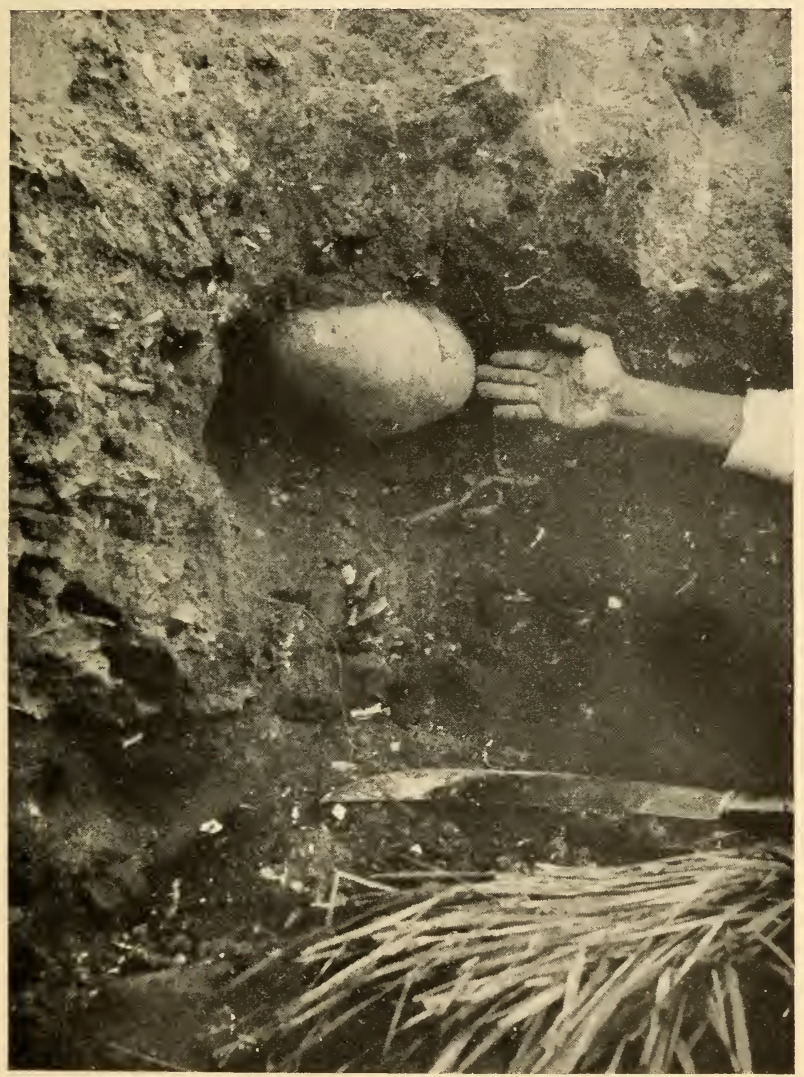

BURIAL VESSEL IN SITU 



\section{PET R O G L Y P H S.}

extremely hard. The method followed in excavating was first to remove the aboriginal deposit under the diluvium and to then break down the overhanging shelf of earth (fig. 3). By these means the artifacts in the lower layers were removed without breakage. The sloping contour of the ridge, mentioned above, may be seen in the illustration referred to.

A number of burials were found in the kitchen-middens at Salt river. The same method of interring the dead was practised as at the Magen's Bay site. By reason of the richness of the soil and its dampness, there was no possibility of preserving the skeletal material. As at Magen's bay, a number of burials were accompanied with pottery vessels, one of which is illustrated in pl. $\mathrm{v}$.

PETROGLYPHS OF ST JOHN AND OF CONGO $\mathrm{CAY}$

On the southern coast of the island of St John is an inlet named Reef bay on modern charts. This inlet may be seen also on older charts under the names Kip

\section{A N D M NOGRAPHS}




\begin{tabular}{|l|l|}
\hline 48 & \multicolumn{1}{|c|}{ V I R G I N I S L A N D S } \\
\hline $\begin{array}{l}\text { bay and Rif bay, but the appellation in } \\
\text { common use is Reef bay, and it probably } \\
\text { originated from the fact that this body } \\
\text { of water is bordered by a coral reef. In } \\
\text { former days the Reef Bay estate seems to } \\
\text { have been of considerable importance as } \\
\text { a sugar factory, but with the abolition } \\
\text { of slavery and the decline in price of } \\
\text { sugar, the estate suffered a serious de- } \\
\text { cline, as did numerous other sugar plan- } \\
\text { tations on the island. } \\
\text { The writer is indebted to Mrs L. } \\
\text { Marsh, present owner of the Reef Bay } \\
\text { estate, and to her son, Mr E. Marsh, for } \\
\text { permission to make photographs of the } \\
\text { property, and special thanks are due Mr } \\
\text { Marsh for his courtesy in acting as guide } \\
\text { to the writer during his visit to the estate. } \\
\text { Following the road between Lamesure, } \\
\text { another bay on the southern coast of St } \\
\text { John, situated more easterly than Reef } \\
\text { bay, one views from a considerable dis- } \\
\text { tancethe waterfalls under which the rock- } \\
\text { carvings are found. The falls lie between } \\
\text { the ridges of two hills, and in reality con- } \\
\text { sist of two cataracts, the upper one al- }\end{array}$ \\
\hline$\quad$ I N D I A N N O T ES \\
\hline
\end{tabular}




\section{PET R O GL Y P H S}

most $60 \mathrm{ft}$. high, and the lower, under which the carvings are found, $45 \mathrm{ft}$. in height. As the crow flies the falls are not more than a mile and a quarter from the sea.

In order to visit the site, it is necessary to follow the dry bed of a stream and then to cut one's way through a somewhat dense thicket. Before the hurricane of October 9, I9I6, a foot-path followed the watercourse, hence the ascent to the falls was far easier than it is today.

The lower fall is not of considerable volume in ordinary times, but during heavy rains the quantity of water that passes over the rocks must be quite large. It appears that in the present times, even during extended periods of drought, the falls are active, therefore it may be said that in Indian days, when the island was more heavily wooded than it is now, they never ceased.

The lower waterfall discharges into a pool about $5 \mathrm{ft}$. deep and $\mathrm{I} 2 \mathrm{ft}$. in diameter, which in turn empties into a second pool about seven feet lower. This lat-

\section{A N D M ONOGRAPHS}




\begin{tabular}{|c|c|}
\hline 50 & VIRGIN ISLANDS \\
\hline * & $\begin{array}{l}\text { ter pool, in which the water is quite } \\
\text { tranquil, is about } 61 / 2 \mathrm{ft} \text {. deep, I4 ft. } \\
\text { wide, and } 9 \mathrm{ft} \text {. broad. The water, filtered } \\
\text { during its long course through the hills, } \\
\text { is excellent for drinking purposes, and } \\
\text { doubtless the Indians visiting the south- } \\
\text { ern coast of St John must have come here } \\
\text { for their supply. } \\
\text { It is on the rocks surrounding the lower } \\
\text { pool that the petroglyphs are found. } \\
\text { Fig. } 4 \text { illustrates the carvings on the up- } \\
\text { per part of the large rock above this pool, } \\
\text { which are not very remarkable. The fig- } \\
\text { ure at the extreme left is } 19 \text { in. long, while } \\
\text { its largest circle is Io in. in diameter. } \\
\text { This glyph probably represents a con- } \\
\text { ventionalized human figure. The size of } \\
\text { the other etchings shown in this illustra- } \\
\text { tion may be determined from the dimen- } \\
\text { sions of the one described. Another con- } \\
\text { ventionalized human figure is shown at } \\
\text { the middle of the photograph, directly } \\
\text { above which may be seen (one of them } \\
\text { rather faintly) two human faces, each } \\
\text { outlined by a circle, with two pits for the } \\
\text { eyes and a line for the mouth. The sig- }\end{array}$ \\
\hline I & I NDIAN NOTES \\
\hline
\end{tabular}




\section{PE T R O G L Y P H S}

nificance of the intricate figure between the two conventionalized human heads is not known, and the same may be said

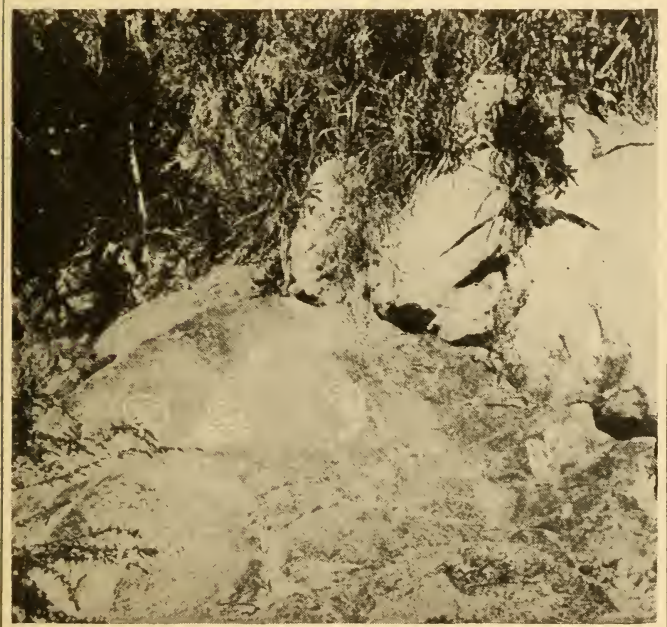

Fig. 4.-Petroglyphs on a large rock above the second pool.

of the carving at the extreme right-hand side of the illustration.

On the surface of the lower part of the same rock, shown in fig. 5, there are other carvings, and unless the Indians

\section{A N D MONOGRAPHS}




\begin{tabular}{|c|c|}
\hline 52 & VIRGIN ISLANDS \\
\hline & $\begin{array}{l}\text { stood in the pool while making them, } \\
\text { they must have been produced while the } \\
\text { workers lay prone upon the rock. The } \\
\text { presence of the line of pits is noteworthy, } \\
\text { especially as it is directly above the nor- } \\
\text { the } \\
\text { Fis. 5-Petroglyphs on the lower part of the large } \\
\text { rock above the second pool. } \\
\text { mal water-line of the pool, which it al- } \\
\text { most parallels. At the extreme left of } \\
\text { the photograph we find the usual con- } \\
\text { ventional face, consisting of a circle, two } \\
\text { pits, and a line. A similar carving may } \\
\text { be seen a little to the right and somewhat }\end{array}$ \\
\hline I & I N D I A N NOTES \\
\hline
\end{tabular}




\begin{tabular}{l|l|}
\hline P E T R O G L Y P H S. & 53 \\
\hline higher, directly under which is a carving \\
of the same character, excepting that the \\
eyes are shown somewhat more elabor- \\
ately by pits surrounded by semicircular \\
lines. The large figure above, beneath \\
the bush, cannot be explained. Under \\
this device, a little to the right, are two \\
scroll-like carvings which more than \\
likely were designed to represent two \\
pairs of human eyes. To the right of \\
these is a conventionalized human figure, \\
the large circle outlining the face, with \\
inner lines for eyes and mouth, the four \\
lines under the circle representing arms \\
and legs. Above this carving, to the \\
right, is what probably was another hu- \\
man figure, of which the lines represent- \\
ing the left hand, arms, and legs have \\
been obliterated by the elements. In the \\
picture writings at the extreme right, \\
conventionalized eyes are again repre- \\
sented. In order to afford an idea of the \\
size of these carvings, it may be said that \\
the distance from the human face at the \\
extreme left side of the picture to the \\
carvings on the extreme right is Io ft.,
\end{tabular}




\begin{tabular}{|c|c|}
\hline 54 & V I R G I I L A N D S \\
\hline & $\begin{array}{l}4 \text { in. The distance from the top of the } \\
\text { large figure below the bush to the water- } \\
\text { line is } 2 \mathrm{ft} \text {., } 3 \mathrm{in} \text {. } \\
\text { Only three figures are found on the } \\
\text { rocks at the western side of the pool under } \\
\text { Fig. 6.-Petroglyph on western side of the lower pool. } \\
\text { the second waterfall (fig. 6). The lower- } \\
\text { most of these is a cross, the height of } \\
\text { which is I } 7 \text { in. and the width II in. It } \\
\text { cannot be urged that the Indians inhab- } \\
\text { iting or visiting St John derived this } \\
\text { conception from the Christian teachings of }\end{array}$ \\
\hline I & I NDIAN NOTES \\
\hline
\end{tabular}




\begin{tabular}{|l|l|}
\hline P E T R O G L Y P H S & S5 \\
\hline the discoverers of the New World, as the \\
petroglyphs probably existed many years \\
before the coming of the Spaniards. \\
This carving may have represented a \\
conventional swastika symbol for desig- \\
nating the four cardinal points. The in- \\
tricate carving directly above is beyond \\
explanation, as is the one shown at the \\
extreme left. \\
All carvings at Reef bay are of about \\
the same depth, namely, about a quarter \\
of an inch. Other petroglyphs existed \\
on these rocks in pre-Columbian times, \\
but they have been almost, and in some \\
cases entirely, obliterated by weathering. \\
A series of small cays and islets lies be- \\
tween St Thomas and St John. One of \\
the larger of these is called Lovango cay, \\
and directly north of it is a rocky cay \\
called Congo cay. The farm is owned \\
in part by Mr Andersen, to whom the \\
writer is indebted for permission to visit \\
Congo cay, which is leased by the owner \\
as a fishing station. \\
Congo cay, with its single landing- \\
place accessible only by rowboat, con-
\end{tabular}




\begin{tabular}{|c|c|}
\hline 56 & VIRGIN ISLANDS \\
\hline & $\begin{array}{l}\text { sists of a rocky ridge, in shape somewhat } \\
\text { resembling the fin of a shark. The cay } \\
\text { is practically devoid of vegetation, and } \\
\text { its only advantage is that it seems to be } \\
\text { the best station for line-fishing in the } \\
\text { waters surrounding St Thomas and St } \\
\text { John. There is no place on the cay that } \\
\text { would have afforded facilities for beach- } \\
\text { ing Indian canoes, hence such visitors as } \\
\text { may have come to the cay must have been } \\
\text { taken there by their tribesmen who were } \\
\text { obliged to return later to carry them } \\
\text { away. } \\
\text { The petroglyphs of Congo cay are on } \\
\text { the rock at the extreme eastern part (fig. } \\
7 \text {, } 8 \text { ). It will be noted that the rock } \\
\text { is almost horizontal and that it faces the } \\
\text { islet known as Caravel rock, to the east- } \\
\text { ward. The cavity in the middle of the } \\
\text { rock is not artificial, as some have sup- } \\
\text { posed, but was caused by the decompo- } \\
\text { sition of the stone. Several rocks on } \\
\text { Congo cay have similar cavities. } \\
\text { The petroglyphs here, shown in detail } \\
\text { in fig. } 8 \text {, are the only ones to be seen on } \\
\text { Congo cay, and are singularly uninter- }\end{array}$ \\
\hline I & I NDIAN NOTES \\
\hline
\end{tabular}




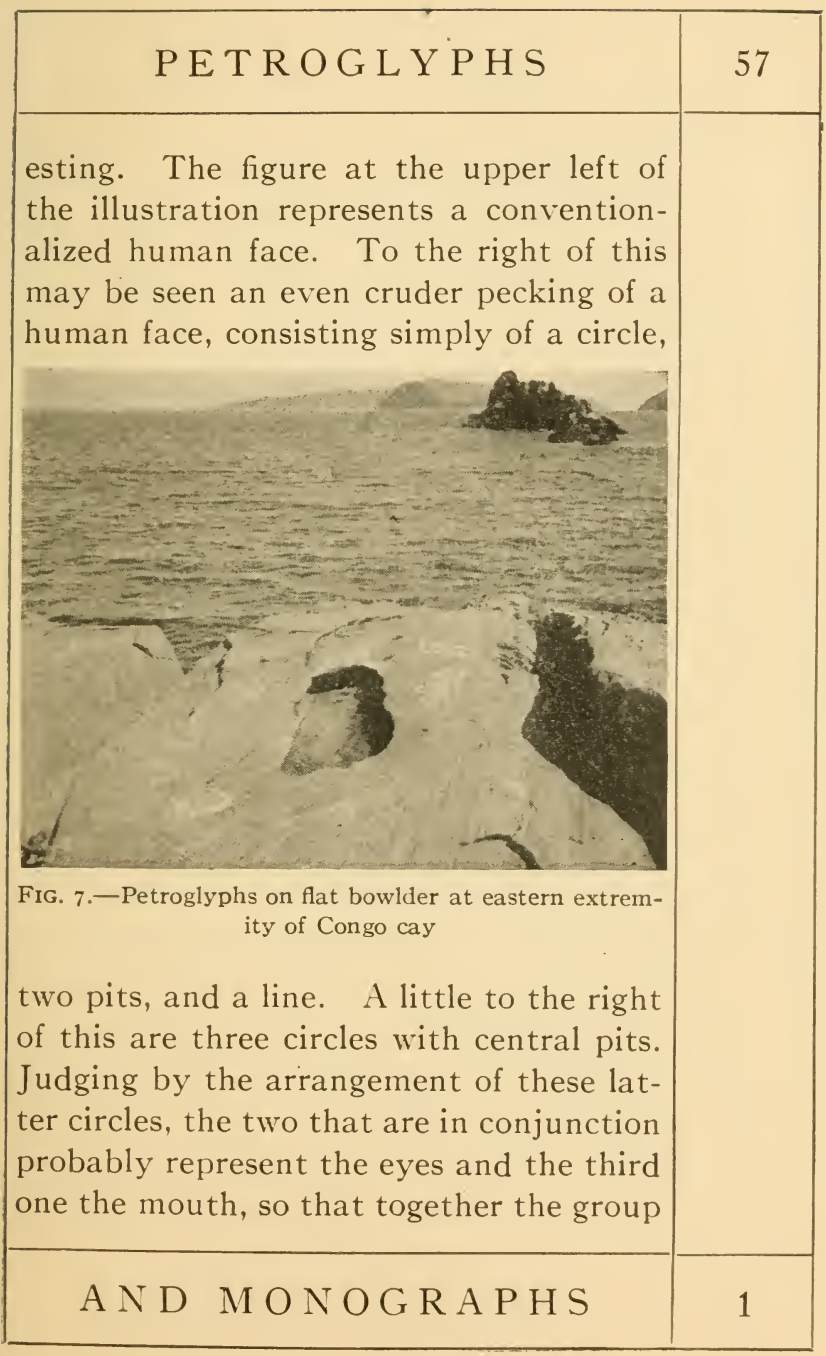




\begin{tabular}{|c|c|}
\hline 58 & VIRGIN ISLANDS \\
\hline • & $\begin{array}{l}\text { was designed to represent a human face. } \\
\text { In the lower center of the picture is a } \\
\text { circle enclosing two conjoined circles with } \\
\text { the usual pits. The largest circle in this } \\
\text { case has an appendage of four lines and } \\
\text { are. Above and to the right of this are } \\
\text { two concentric circles with a central pit. } \\
\text { As on Reef bay, it is likely that a much } \\
\text { Fig. 8.-Petroglyphs on bowlder, and cavity in the } \\
\text { a done. } \\
\text { depresents a conventionalized human fig- } \\
\text { are the entire carving probably }\end{array}$ \\
\hline I & I N D I A NOTES \\
\hline
\end{tabular}




\begin{tabular}{|l|l|}
\hline P E T R O G L Y P H S & 59 \\
\hline greater number of petroglyphs existed \\
upon this rock in pre-Columbian times \\
and that the action of wind and water has \\
obliterated many of them. The carvings \\
are about a quarter of an inch deep. As \\
an indication of the size of the petro- \\
glyphs, it may be said that the width of \\
the cavity shown in the illustration is 3 \\
in., the depth $31 / 2$ in., and the length 44 \\
in. From the figure at the extreme left \\
of fig. 8 to that on the extreme right is \\
$3 \mathrm{I} 1 / 2$ in. The rock itself is about 35 ft. \\
above sea level. \\
Evidence was discovered on Lovango \\
cay that it had been inhabited in pre- \\
Columbian times, hence it is probable \\
that members of the tribe came to Congo \\
cay to fish. IWhat appears to be an arti- \\
ficial mortar hole, about 5 in. in diameter \\
and 4 in. deep, exists in one of the rocks \\
near that on which the carvings are found. \\
It is possible that this depression was \\
used by the Indians for pounding the salt \\
used for curing the fish caught during \\
their stay on the cay. \\
\begin{tabular}{l} 
A N D M O N O G R A P H S \\
\hline
\end{tabular}
\end{tabular}




\begin{tabular}{|c|c|}
\hline 60 & VIRG I N ISLA N D S \\
\hline & $\begin{array}{l}\text { THE ARTIFACTS } \\
\text { As the artifacts found on St Thomas } \\
\text { and St Croix pertain to the same culture, } \\
\text { it is permissible to discuss them as a } \\
\text { whole, regardless of the particular is- } \\
\text { lands from which they respectively came. } \\
\text { EARTHENwARE } \\
\text { BURIAL vessels } \\
\text { IVithout exception, the vessels that ac- } \\
\text { companied the burials are sererely plain, } \\
\text { being devoid of painted, incised, or im- } \\
\text { pressed decoration. The receptacles vary } \\
\text { m }\end{array}$ \\
\hline $\mathrm{I}$ & I N D I N NOTES \\
\hline
\end{tabular}




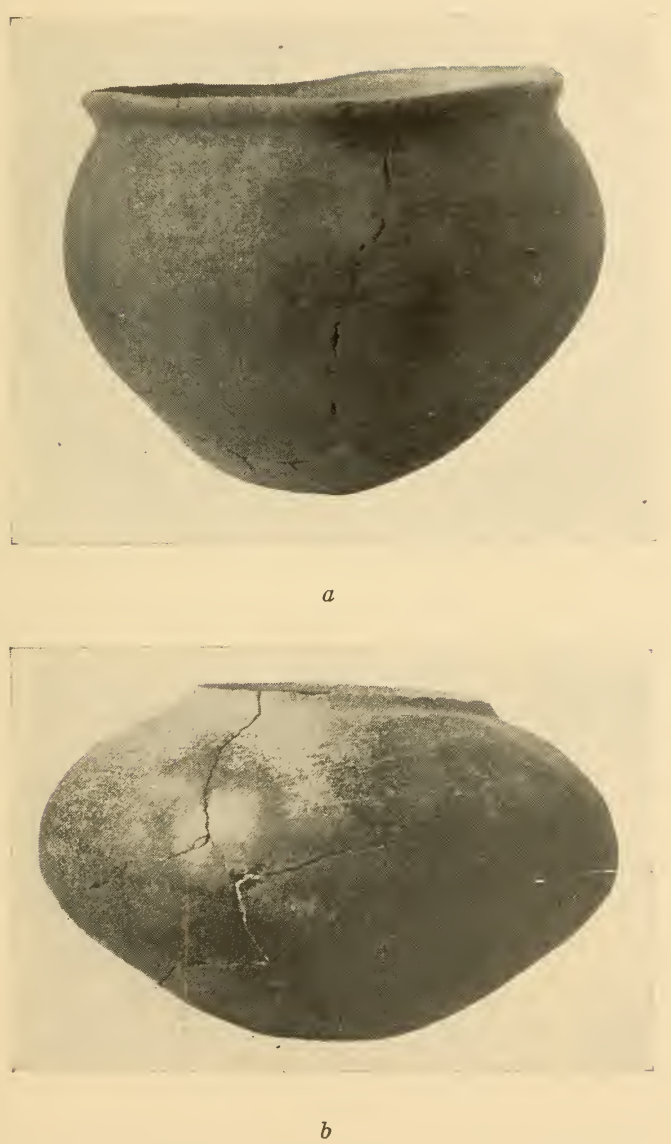

BURIAL VESSELS FROM SALT RIVER, ST CROIX 



\section{B URIAL VESSELS}

Most of the mortuary vessels are globular, with large mouth, outcurving rim, and rounded or flattened base (pl. vI, a). Receptacles of this type vary in size from one with a rim diameter of $3 \frac{1}{2}$ in. to another with a diameter of $81 / 2$ in. In ad-

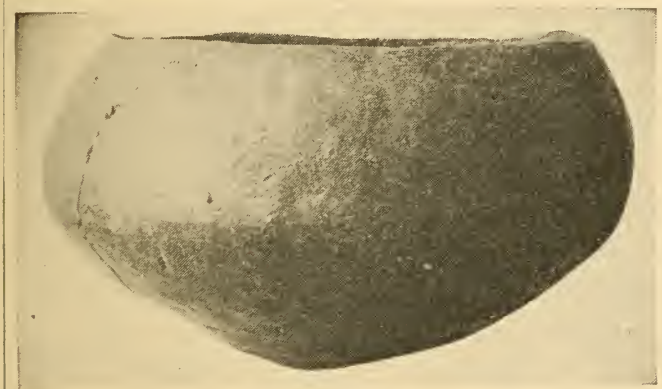

FIG. I0.-Burial vessel from Magen's bay, St Thomas.

dition to the mortuary vessels of the form mentioned, the graves revealed two with similar bodies but with mouths proportionately much smaller than in the specimens referred to. One of these, in situ, is shown in pl. $\mathrm{v}$ and in detail in pl. vi, $b$. The diameter of this vessel at the mouth is only $5 \frac{1}{2}$ in., while that of

A ND MONOGRAPHS 


\begin{tabular}{|c|c|}
\hline 62 & VIRG I N ISLANDS \\
\hline & $\begin{array}{l}\text { the body is II } 3 / 4 \text { in. One shallow bowl } \\
\text { was found, identical to the oval bowl il- } \\
\text { lustrated in fig. 9, excepting that it is } \\
\text { rounded instead of oval. Finally, there } \\
\text { was recovered a vessel the bottom of } \\
\text { which is rounded while the upper part } \\
\text { curves regularly inward until it meets the } \\
\text { slightly flaring rim (fig. I I). } \\
\text { The shallow, oval bowl shown in fig. } \\
9 \text { is of well-fired, yellow clay; it stands } \\
21 / 2 \text { in. high and has an inside depth of } \\
21 / 4 \text { in., the thickness of the ware thus } \\
\text { being a quarter of an inch. The rim has } \\
\text { a slight inward curve. The diameters of } \\
\text { the vessel are } 9 \text { in. and } 71 / 2 \text { in., and the } \\
\text { rim at the longer ends is slightly higher } \\
\text { than at the middle. This vessel was } \\
\text { found on St Thomas in the Magen's Bay } \\
\text { mound. } \\
\text { The largest vessel found (fig. Io) has a } \\
\text { maximum diameter of } 171 / 2 \text { in. and a rim } \\
\text { diameter of I } 1 / 2 \text { in.; it is Io } 1 / 2 \text { in. in } \\
\text { height, and is of well-fired, dark-brown } \\
\text { ware, three-eighths of an inch thick. } \\
\text { This receptacle also is from the Magen's } \\
\text { Bay mound. }\end{array}$ \\
\hline I & I NDIAN NOTES \\
\hline
\end{tabular}




\section{B URIAL VESSELS}

The vessel illustrated in pl. vi, $a$, from the Salt River deposits on St Croix, is an example of several found on both $\mathrm{St}$ Croix and St Thomas. The one here shown is $73 / 4 \mathrm{in}$. in height; it has a globular body with a diameter of $9 \frac{1}{2}$ in., while its mouth, with a slightly outcurving rim, is $81 / 2 \mathrm{in}$. in diameter. The base is rounded. This vessel is of light-brown clay, well-fired, with a thickness of a quarter of an inch.

The jar shown in pl. vi, $b$, resembles the type last described, excepting that the diameter of the mouth is small in proportion to that of the body. The rim is missing, but it was probably only half an inch high, and its lower part has a gentle outward curve. The boomtt of the vessel is slightly flattened. This receptacle, which was found in the Salt River deposits on St Croix, is of hard-fired, reddish ware; it stands $71 / 4 \mathrm{in}$. high, and its walls are three-eighths of an inch thick. A similar vessel was found on St Thomas.

Only one vessel of the type illustrated in fig. II was found. This jar has a

\section{A ND MONOGRAPHS}




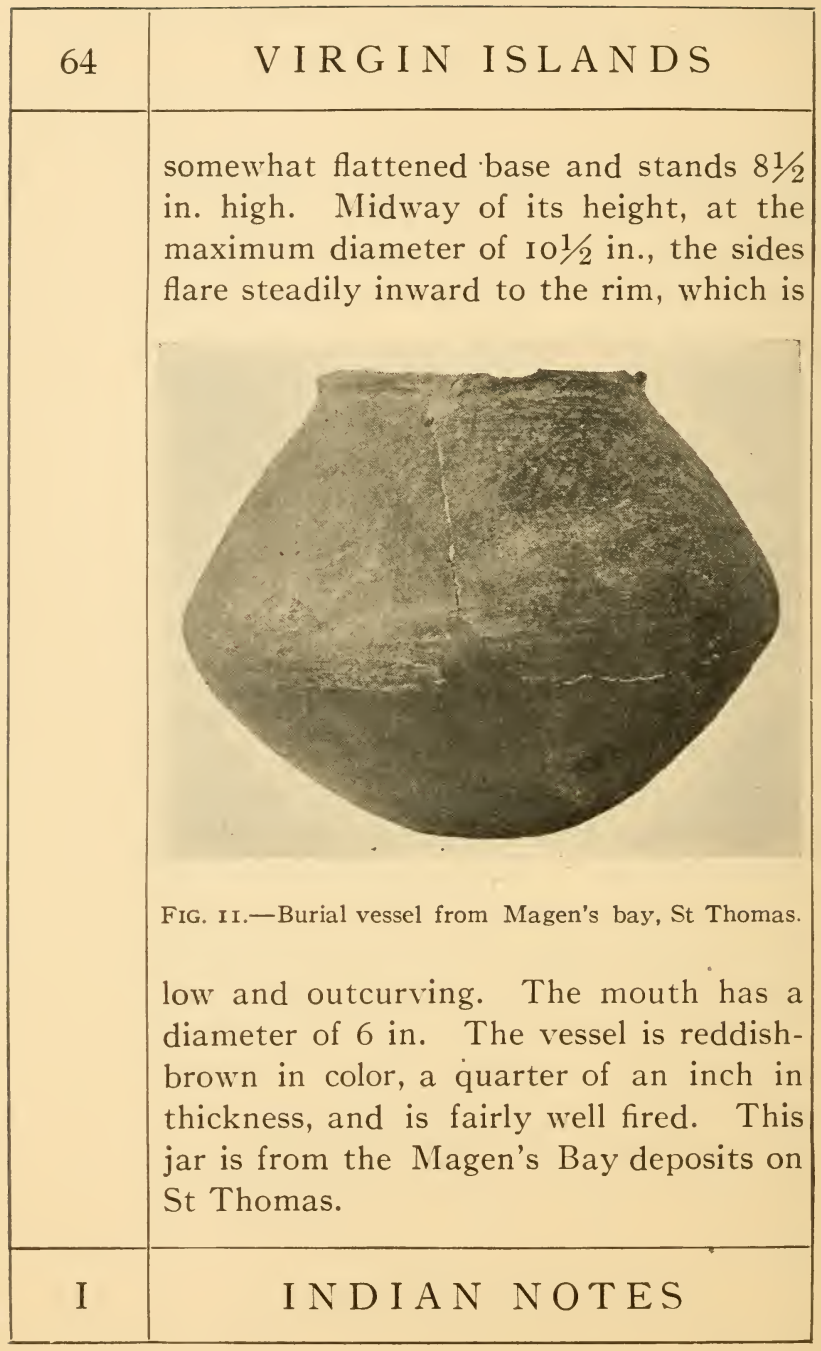




\begin{tabular}{|l|l|}
\hline E A R T H E N W A R E & Th \\
\hline orHER POTrERY RECEPTACLES & \\
Pottery vessels from St Thomas and & \\
St Croix may be segregated into two \\
classes: those having painted decoration \\
and those having none. Of both varie- \\
ties representative specimens have been \\
selected for description. It would be im- \\
practicable to describe and illustrate the \\
thousands of earthenware objects recov- \\
ered from St Thomas and St Croix, but \\
the comparatively few descriptions given \\
may be taken as illustrative of the ceramic \\
art of the two islands. \\
Generally speaking, the plain pottery \\
from the two islands is the crudest found \\
in the Antilles. The elaborate incised \\
and impressed decorations so common to \\
the vessels from the Greater Antilles are \\
entirely lacking here, as are the grotesque \\
but well-modeled heads so typical of both \\
the Greater and the Lesser Antilles. On \\
the other hand, there are types that bear \\
no resemblance to those of other West \\
Indian islands. \\
The boat-shaped vessel shown in fig. \\
I2 is not unusual, for this form occurs on \\
\hline A N D M O N O G R A P H S
\end{tabular}




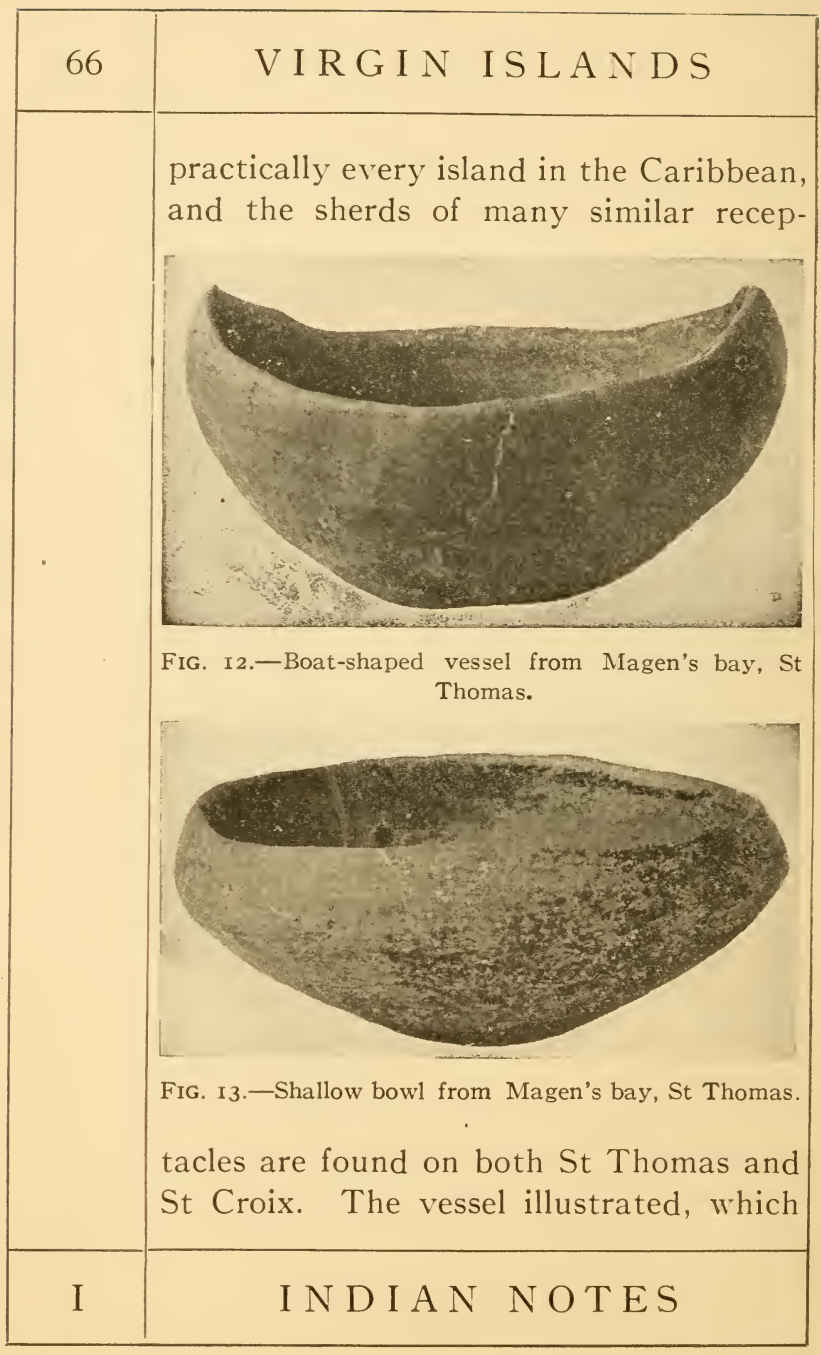




\section{E A R T H E N W A R E}

has a flattish base, stands 4 in. high at the middle, while the ends, which are slightly pointed, reach a height of $5 \frac{1}{2}$ in. The longer axis is $9 \mathrm{in}$. and the shorter $81 / 2 \mathrm{in}$. The ware is a quarter of an inch thick, and is of well-fired, dark-brown clay. This specimen was found in the Magen's Bay middens of St Thomas, and doubtless served for culinary purposes.

Another simple and not uncommon West Indian type of bowl is shown in fig. I3. This little vessel, which has a flattish base, stands 3 in. high; it has a slightly incurving rim, a diameter at the mouth of $61 / 2$ in., while that of the body is $7 \frac{1}{4} \mathrm{in}$. The ware is three-eighths of an inch in thickness. The vessel is of poorly fired, reddish clay, and probably served as a food-bowl. Countless sherds of vessels of this type, in all sizes, were found in both the Magen's Bay and the Salt River deposits. The specimen illustrated is from the former locality.

Small, shallow, rounded bowls, with plain rims or with two handle-like projections from the rim, such as are shown

\section{A ND MONOGRAPHS}




\begin{tabular}{|c|c|}
\hline 68 & VIRGIN ISLA N D S \\
\hline & $\begin{array}{l}\text { Fig. I4--Shallow bowl with nodes, from Magen's bay, } \\
\text { St Thomas. } \\
\text { quarter of an inch in thickness. This } \\
\text { specimen was found in the Magen's Bay } \\
\text { deposits of St Thomas. } \\
\text { The platter shown in fig. I } 5 \text { is of a type } \\
\text { not hitherto found in the Antilles. It } \\
\text { resembles the familiar cassava griddles } \\
\text { found on practically every island from } \\
\text { the Bahamas to Trinidad, but is too small }\end{array}$ \\
\hline I & I N I A N NOTES \\
\hline
\end{tabular}




\section{E A R T H E N W R E}

to have been used for the same purpose. Many sherds of platters of this kind were found on both St Thomas and St Croix.

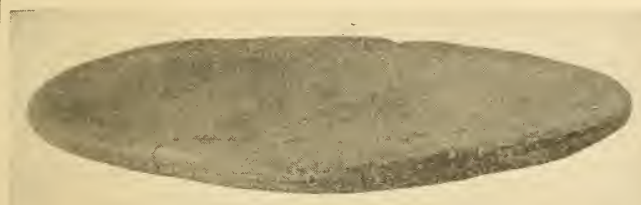

FIG. I5.-Platter from Salt river, St Croix.

The one illustrated, from the Salt River deposits on the latter island, has a diameter of $83 / 4$ in.; it is slightly concave, and

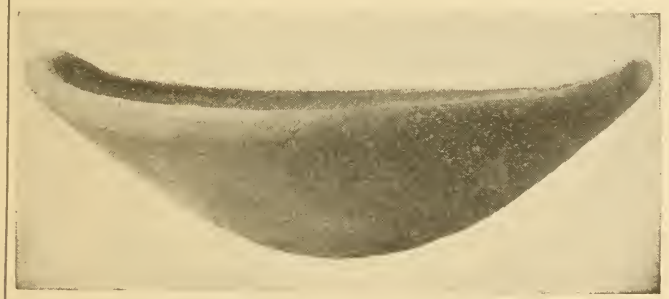

FIG. I6.-Boat-shaped vessel from Salt river, St Croix. the ware, which is of well-fired, brown clay, is three-eighths of an inch thick.

The large vessel illustrated in fig. I6, from the Salt River deposits of St Croix,

\section{A ND MONOGR A P H S}




\begin{tabular}{|c|c|}
\hline 70 & VIRGIN ISLANDS \\
\hline & $\begin{array}{l}\text { may also be considered representative of } \\
\text { the culture of the Virgin Islands, as it is } \\
\text { not found on any other islands of the } \\
\text { West Indies, so far as known. Practically } \\
\text { a third of the sherds of household vessels } \\
\text { found on St Thomas and St Croix belong } \\
\text { to receptacles of this character. It is } \\
\text { boat-shaped, and the ends of the longer } \\
\text { axis terminate in double nodes evidently } \\
\text { modeled with the thumbs. The length } \\
\text { of the vessel is I9 in., its width } 53 / 4 \text { in.; } \\
\text { it stands } 5 \text { in. high. The ware is three- } \\
\text { eighths of an inch thick, and is of fairly } \\
\text { well fired, dark-brown clay. The rim is } \\
\text { slightly incurving and the base is rounded. } \\
\text { Sherds of small, globular vessels with } \\
\text { loop handles, of which a typical example } \\
\text { is shown in pl. vir, were also found in } \\
\text { abundance on the Virgin Islands, but } \\
\text { have not been noted heretofore on other } \\
\text { islands of the Antilles. When complete, } \\
\text { the vessel illustrated was globular in } \\
\text { shape, with a slightly incurving rim. The } \\
\text { diameter of the mouth is } 3 / 4 \text { in., and of } \\
\text { the body } 53 / 4 \text { in. This little receptacle } \\
\text { stands } 5 \text { in. high, is made of well-fired, }\end{array}$ \\
\hline I & I NDIAN NOTES \\
\hline
\end{tabular}




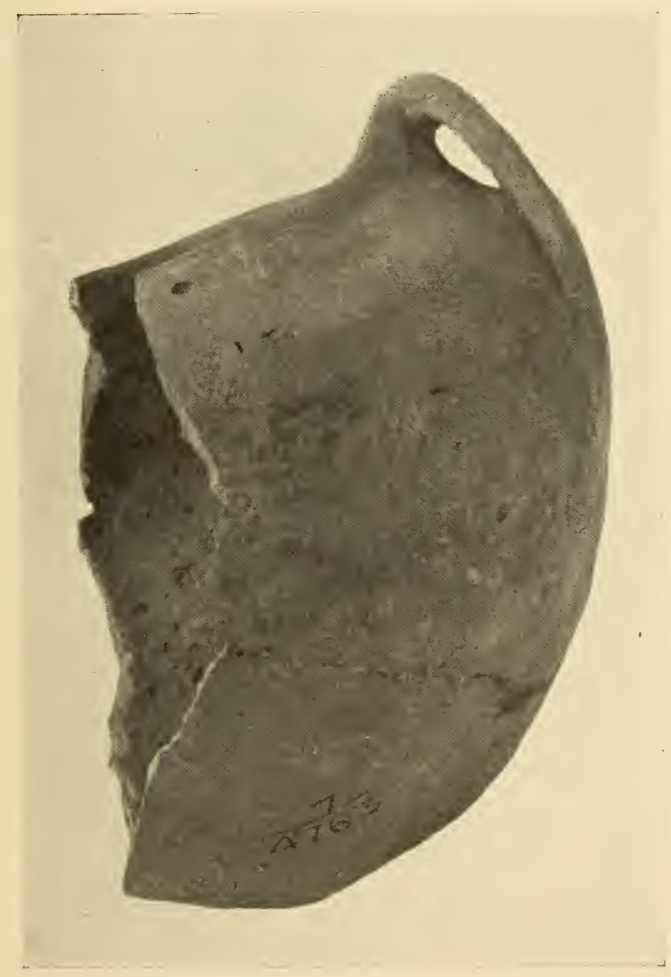

SHERD OF GLOBULAR BOWL WITH LOOP HANDLE, FROM MAGEN'S BAY, ST THOMAS 



\section{E A R T H E N W A R E}

reddish-brown clay, the walls being onequarter of an inch thick. Only one handle is shown on the sherd illustrated, but there can be no doubt that the receptacle had been provided with a similar handle on the side now missing. The specimen illustrated was found in the Magen's Bay deposits of St Thomas.

A fragment of a utensil was found in the Salt River deposits on St Croix which indicates that the aborigines of the Virgin Islands were familiar with the use of double vessels. This sherd (pl. vili, a) shows two elliptical, flattish bases on the under side. A partition, one inch high with rounded edge, dividing the bowl in two parts, extends perpendicularly from the inside. It may be conjectured that the height of the bowl, when entire, did not exceed $\mathrm{I} / 2$ in., while the diameter of the mouth was probably about $4 \frac{1}{2}$ in.

Another unusual sherd was found in the Salt River deposits of St Croix which recalls one collected by Mr M. R. Harrington in eastern $\mathrm{Cuba}$ and another by the writer in western Porto Rico. This

\section{A ND MONOGRAPHS}




\begin{tabular}{|c|c|}
\hline 72 & VIRGIN ISLANDS \\
\hline & $\begin{array}{l}\text { fragment, shown in pl. vII, } b \text {, evidently } \\
\text { belonged to a round bowl provided with a } \\
\text { double, parallel rim, possibly for the pur- } \\
\text { pose of accommodating a convex lid, al- } \\
\text { though no sherds of such a lid were found. } \\
\text { The inner rim of the sherd, which is } \\
\text { slightly incurving, follows the contour of } \\
\text { the bowl, while the outer rim, which is } \\
\text { slightly lower than the inner one and is } \\
\text { separated therefrom by a space of } 1 / 8 \\
\text { in., has an outward flare. } \\
\text { Of vessels and sherds ornamented with } \\
\text { incised or impressed designs, compara- } \\
\text { tively few were found in the Virgin Island } \\
\text { deposits, nor do such specimens as are } \\
\text { decorated in this manner compare favor- } \\
\text { ably with the elaborately ornamented } \\
\text { vessels from Porto Rico and Santo Do- } \\
\text { mingo. The incised lines are invariably } \\
\text { crude, and the patterns simple and poorly } \\
\text { executed. The specimen illustrated in } \\
\text { fig. I } 7 \text { is typical of the examples found. } \\
\text { This small, globular bowl, from the Salt } \\
\text { River deposits of St Croix, has a diameter } \\
\text { of } 41 / 2 \text { in. at the mouth, and stands } 31 / 4 \\
\text { in. high. The ware is a quarter of an }\end{array}$ \\
\hline I & I NDIAN NOTES \\
\hline
\end{tabular}




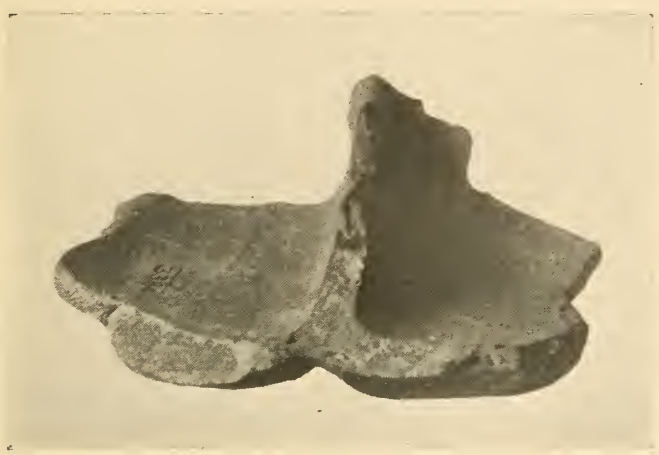

a. Potsherd of a double vessel.

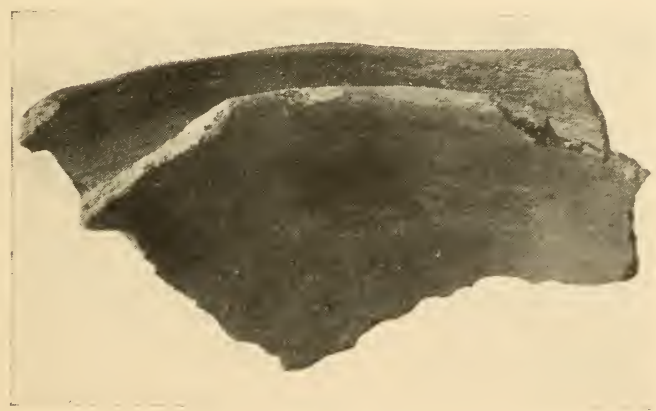

b. Potsherd with a double rim.

SHERDS OF UNUSUAL VESSELS, FROM SALT RIVER, ST CROIX 



\section{N C ISED POT T E R Y}

inch thick, and is of poorly fired, darkbrown clay. The base is rounded. A shallow, incised line parallels the rim. At a distance of from half an inch to an inch below the upper incised line is a

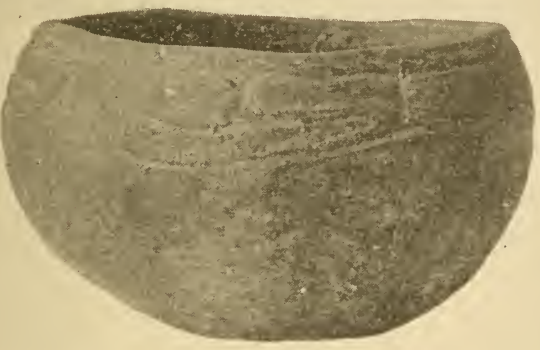

FIG. I7.-Bowl with incised decoration, from Salt river, St Croix.

similar encircling line. At intervals these two lines are connected with vertical incised lines, but there is no symmetry in the spacing, and little attempt was made to produce a pattern. In one or two places a horizontal incised line is seen

\section{A ND M O NGRAPHS}




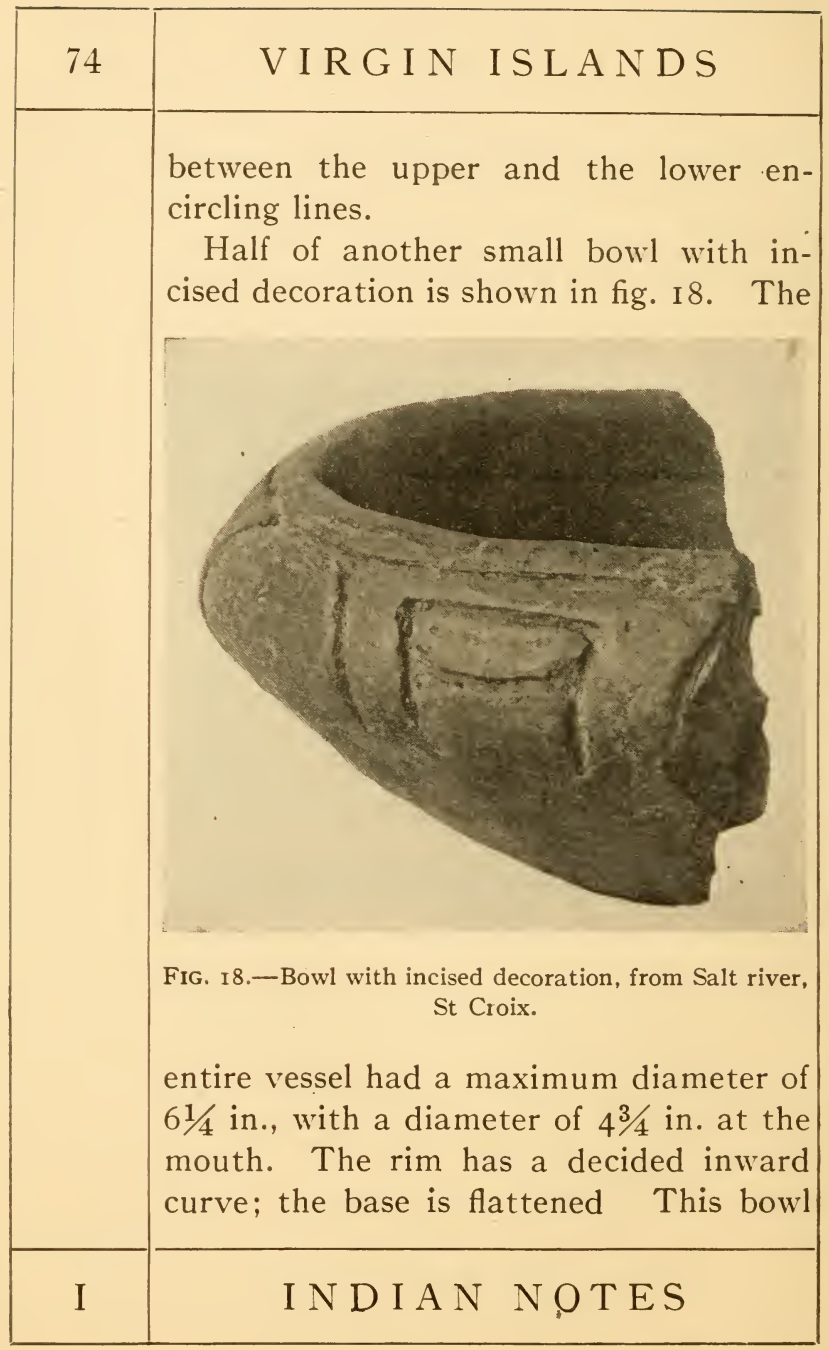




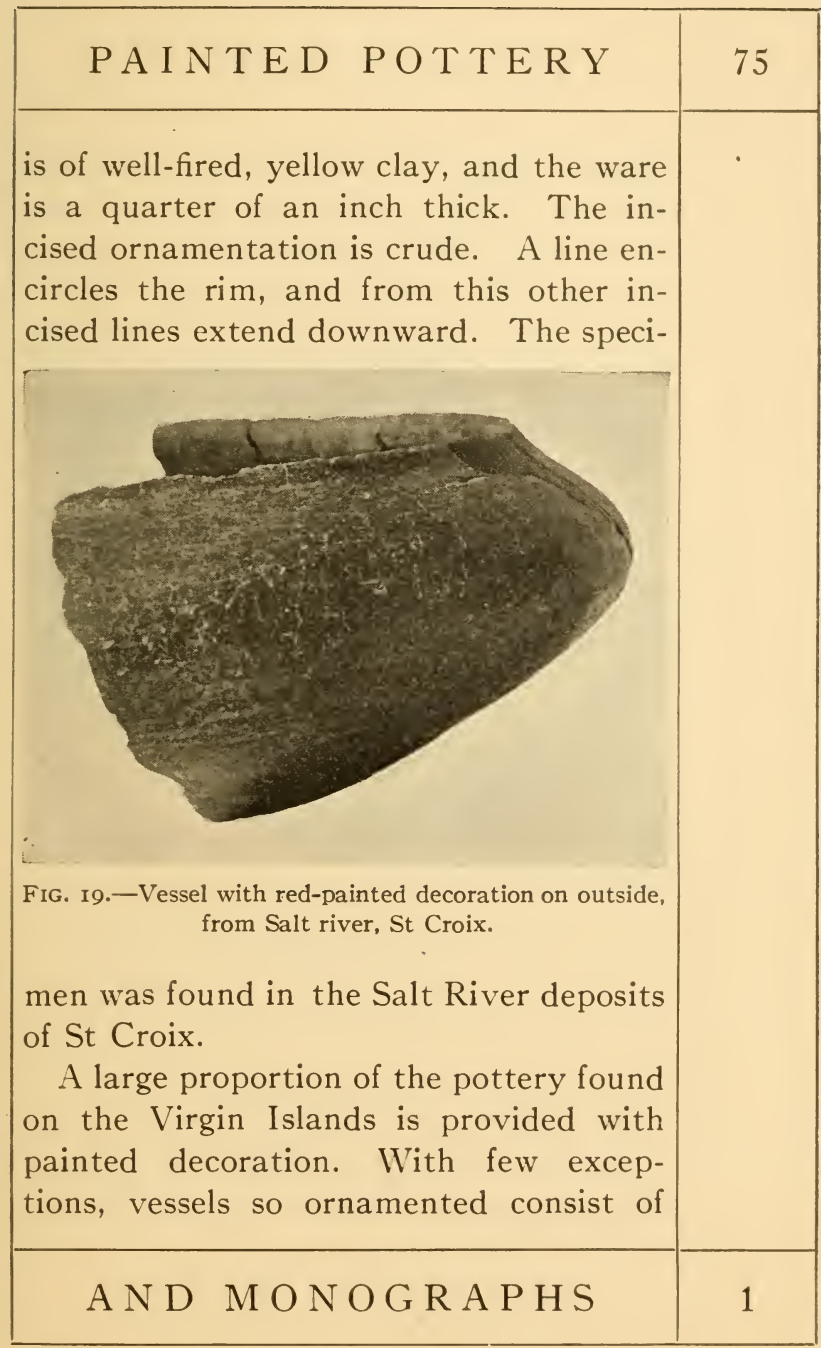




\begin{tabular}{|c|c|}
\hline 76 & VIRGIN ISLANDS \\
\hline & $\begin{array}{l}\text { FIG. 20.- Bowl with painted decoration, from Magen's } \\
\text { bay, St Thomas. } \\
\text { curving rim, which in the entire vessel } \\
\text { had a diameter of } 7 \frac{1}{2} \text { in., while the maxi- } \\
\text { mum diameter of the body was } 91 / 4 \text { in. } \\
\text { The bowl stands } 3 \frac{1}{4} \text { in. high, and has a } \\
\text { flattened base. The ware is a quarter of }\end{array}$ \\
\hline I & I N D A N NOTES \\
\hline
\end{tabular}




\section{PAINTED POTTERY}

an inch thick, and is of well-fired, brown clay. A red slip covers the outside and continues over the rim for a depth of $1 / 2$ in. on the inside. This receptacle was found in the Salt River deposits of St Croix.

Of the simpler forms of painted pottery from the Virgin Islands, the example illustrated in fig. 20 may be considered typical. This sherd is part of a round, very shallow dish, which had a diameter of about $\mathrm{I}_{3}$ in. and a height of only $2 \frac{3}{4}$ in. The rim is rounded at the top and has a slight inward curve. The outside of this platter, which has a flattened base. is of the natural light-brown color of the clay from which it was fashioned, only the inside and the rim having been given the red slip. The ware is a quarter of an inch thick. This utensil was found in the Magen's Bay deposits of St Thomas.

Of the same type as the foregoing, but with a more elaborate painted decoration, is the large, circular, shallow bowl illustrated in fig. 2I. This utensil has a flat-

\section{AND MONOGRAPHS}




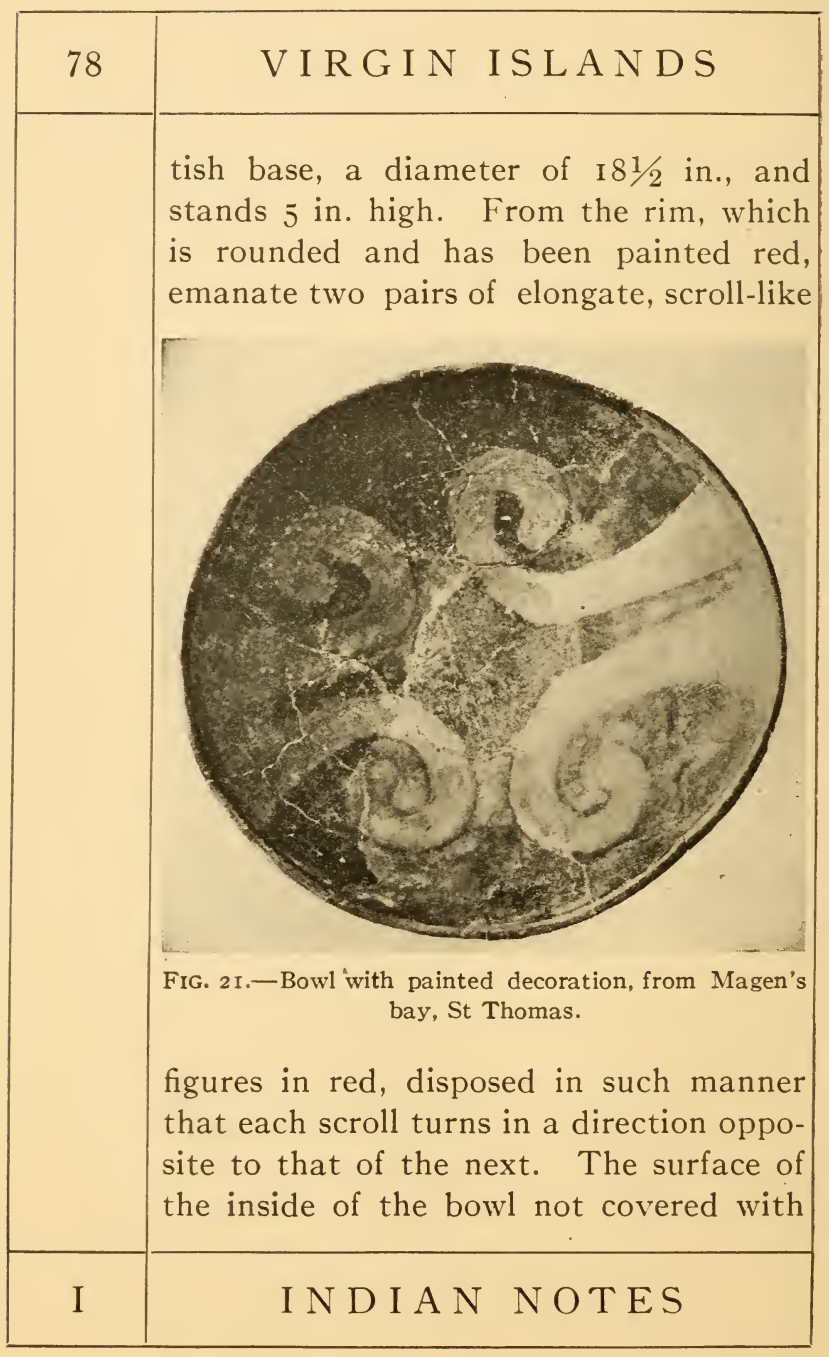




\begin{tabular}{|l|l|}
\hline P A I N T E D P O T T E R Y & 79 \\
\hline the red design is painted black. The \\
outside is in the original reddish-brown \\
color of the clay of which it is made. The \\
receptacle is well-fired and is three-eighths \\
of an inch thick. This specimen was \\
found in the Magen's Bay deposits of St \\
Thomas, but hundreds of sherds of sim- \\
ilar vessels were found on both islands. \\
Still another type of vessel with painted \\
decoration, found abundantly, is illus- \\
trated by the fragmentary example shown \\
in fig. 22. This is a boat-shaped, shal- \\
low dish or platter, of which the oppo- \\
site terminals are provided - with double \\
nodes. This specimen has a length of I2 \\
in. and a width of I $1 / 4$ in.; it stands $31 / 4$ \\
in. high, and has a flattened base. The \\
platter is fashioned from well-fired, red- \\
dish clay, three-eighths of an inch thick, \\
and the outside retains its natural color. \\
The rim of the bowl has been painted red, \\
and the inside is covered with red discs, \\
arranged in two circles between the rim \\
and the red bottom. This specimen was \\
found in the Salt River deposits on St \\
Croix
\end{tabular}




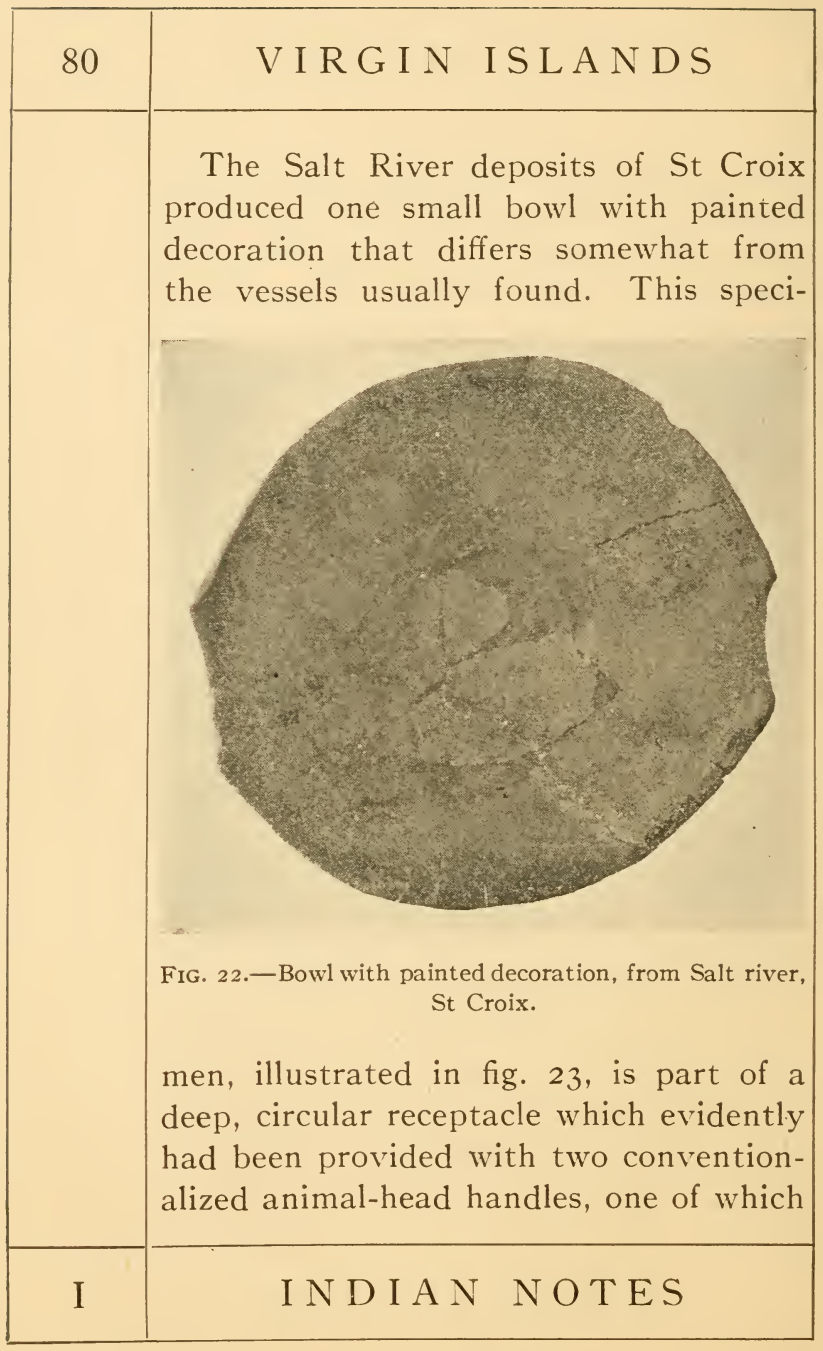




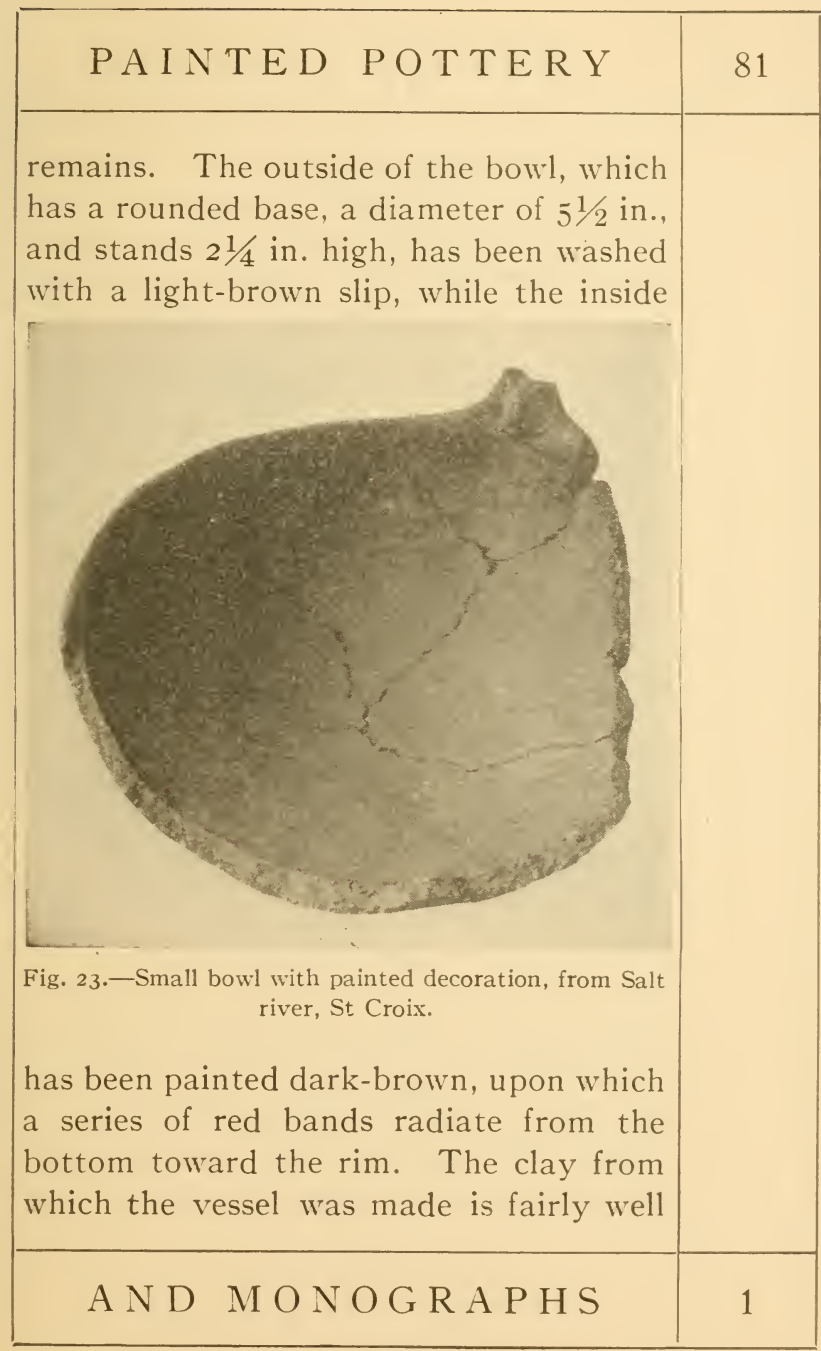




\begin{tabular}{|c|c|}
\hline 82 & V I R G I I L A N D S \\
\hline & $\begin{array}{l}\text { FIG. 24.-Painted sherd with animal head, from Magen's } \\
\text { bay, St Thomas. } \\
\text { Thomas, but there is no doubt that it } \\
\text { was derived from Porto Rico. The sherd } \\
\text { is part of a very large, shallow dish of } \\
\text { which the terminals were provided with } \\
\text { grotesque animal - head handles. The }\end{array}$ \\
\hline I & I N D A N NOTES \\
\hline
\end{tabular}




\section{PAINTED POTTERY}

83

vessel was given a heavy, bright-red slip. It is not possible to determine the size of the bowl of which this is a part; the sherd itself is $I I \frac{1}{2} \mathrm{in}$. long, hence the bowl, when entire, must have been of unusual size.

FIG. 25.-Painted sherd from Salt river, St Croix.

Another interesting sherd, illustrated in fig. 25 , shows a striking resemblance to some of the painted ware found on the island of Trinidad, such as has been illustrated in a former paper. ${ }^{13}$ Not only does the decoration consist of whitepainted lines applied on the red slip that covered the original ware, but the unu-

\section{A ND MONOGRAPHS}




\begin{tabular}{|c|c|}
\hline 84 & VIRGIN ISLANDS \\
\hline & $\begin{array}{l}\text { sually hard-fired clay resembles that of } \\
\text { the painted ware from Trinidad. It } \\
\text { is impossible to determine the shape of } \\
\text { the vessel to which the sherd belonged, } \\
\text { but it probably originated in Trinidad, } \\
\text { as no similar specimens were recovered } \\
\text { from the Salt River deposits of St Croix, } \\
\text { nor are they known from contiguous is- } \\
\text { lands. } \\
\text { Pottery heads, such as are found in all } \\
\text { other West Indian islands, were almost } \\
\text { totally absent from the deposits on St } \\
\text { Thomas and St Croix. The few recov- } \\
\text { ered bear no resemblance to the typical } \\
\text { heads from Porto Rico and Santo Do- } \\
\text { mingo or to those found on the Lesser } \\
\text { Antilles. What undoubtedly was an at- } \\
\text { tempt on the part of the potter to repre- } \\
\text { sent an animal gnawing at an object } \\
\text { which it clutches between its paws, is } \\
\text { shown in fig. } 26 \text {. This handle, which has } \\
\text { been luted to the rim of a vessel, was } \\
\text { found in the Magen's Bay deposits on } \\
\text { St Thomas. }\end{array}$ \\
\hline I & I N D I A N NOTES \\
\hline
\end{tabular}




\section{VESSEL HA N D L ES}

Vessels from the Virgin Islands seem occasionally to have been provided with loop handles of the type illustrated in

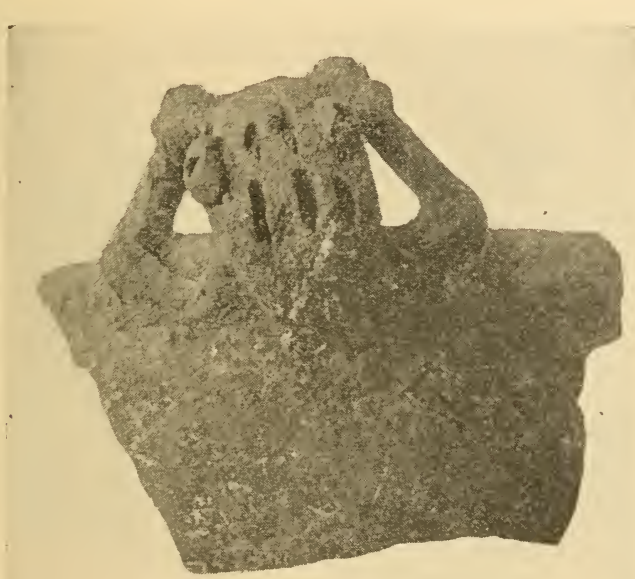

FIG. 26.-Handle with animal figure, from Magen's bay, St Thomas.

fig. 27. The larger of these two was found in the Magen's Bay midden on St Thomas, while the smaller came from the Salt River deposits on St Croix. The

$$
\text { A ND M O NOGR A PHS }
$$




\begin{tabular}{|c|c|}
\hline 86 & VIRG I N ISLA N D S \\
\hline & $\begin{array}{l}\text { Fig. 27--Loop handles with heads. } a \text {, Magen's, bay, } \\
\text { St Thomas; } b \text {, Salt river, St Croix. } \\
\text { painted. A notched ridge extends over } \\
\text { the middle of the handle, and the edges } \\
\text { also are notched. More of the head is } \\
\text { shown than in the larger sherd; the eyes } \\
\text { and nose are in high relief, while a banded } \\
\text { line depicts the outline of the face. }\end{array}$ \\
\hline I & I N D I A N N T ES \\
\hline
\end{tabular}




\begin{tabular}{|c|c|}
\hline S P I N D L E - W H O R L S & 87 \\
\hline $\begin{array}{l}\text { FIg. 28.-Spindle-whorls from Magen's bay, St } \\
\text { Thomas. } \\
\text { the middle. Occasionally a painted sherd } \\
\text { was used for making a disc, but most of } \\
\text { the specimens found were fashioned from } \\
\text { plain pottery fragments. The size of the } \\
\text { perforation varies greatly, in some in- }\end{array}$ & \\
\hline A ND MONOGRAPHS & 1 \\
\hline
\end{tabular}




\begin{tabular}{|c|c|}
\hline 88 & V I R G I I L L N D S \\
\hline & $\begin{array}{l}\text { stances having a diameter of an eighth } \\
\text { of an inch, while in other examples the } \\
\text { diameter is as much as half an inch. } \\
\text { Four specimens are shown in fig. } 28 \text {, of } \\
\text { which the largest has a diameter of } 3 \text { in. } \\
\text { and the smallest a diameter of } 21 / 8 \text { in. } \\
\text { All are from the Magen's Bay deposits on } \\
\text { St Thomas. It may be stated that spin- } \\
\text { dle-whorls have seldom been found in } \\
\text { other West Indian islands, hence the } \\
\text { abundance of specimens of this kind in } \\
\text { the Virgin Islands is rather unusual and } \\
\text { would indicate that the aborigines here } \\
\text { wove textiles to a considerable extent. } \\
\text { cassava GRIDDLEs } \\
\text { Hundreds of fragments of cassava grid- } \\
\text { dles were found on both St Croix and St } \\
\text { Thomas. These in no way differ from } \\
\text { like specimens found on other West In- } \\
\text { dian islands, such as have been described } \\
\text { by the writer in previous papers. }{ }^{14} \text { It is } \\
\text { interesting to note the wide distribution } \\
\text { of specimens of this type throughout the } \\
\text { West Indies. Even where other arti- } \\
\text { facts obtained on the Vrigin Islands are }\end{array}$ \\
\hline I & I N D I A NOTES \\
\hline
\end{tabular}




\section{ST O N E W O K}

so totally distinct in type from those of the adjoining areas, the aborigines of $\mathrm{St}$ Thomas and St Croix appear to have used the same kind of griddles for the preparation of their cassava bread as did the inhabitants of the other islands.

\section{STONE OBJECTS}

In general, the axes and celts found on St Thomas and St Croix are cruder than

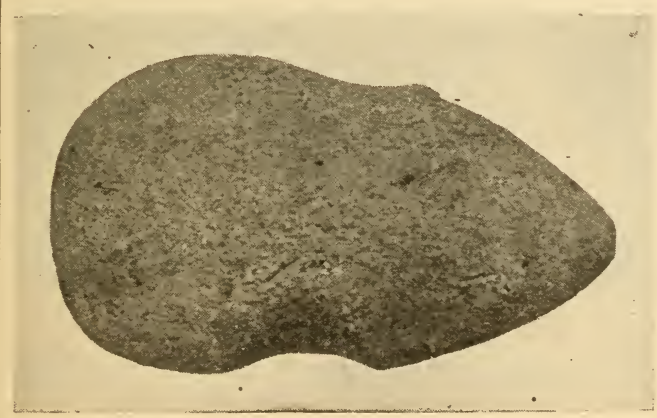

FIG. 29.-Stone axe from St Croix.

those from other islands. The petaloid celts, of which, as well as of the axes, large numbers were acquired by purchase, lack the excellent finish so frequently 


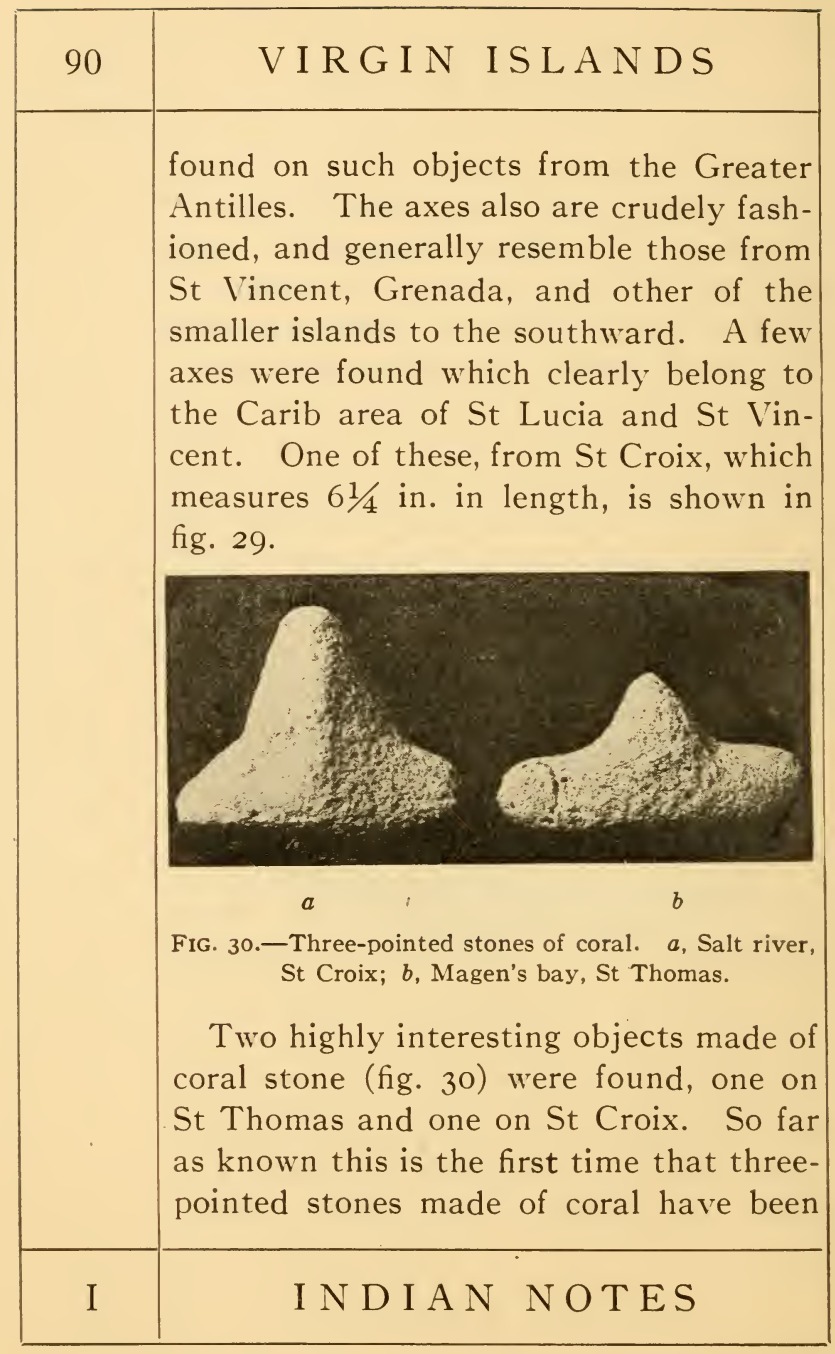




\section{S T O N E W OR K}

discovered in aboriginal deposits in the West Indies. The larger and better finished specimen was found in the Salt River deposits on St Croix, the other in the Magen's Bay deposits of St Thomas. The length of the St Croix specimen is $3 \frac{1}{4}$ in. and the height $2 \frac{3}{4}$ in., while the specimen from St Thomas has a length of $3 \frac{3}{4}$ in. and a height of $17 / 8$ in. These objects bear a typical resemblance to what Dr Fewkes has classified as the "fourth type" of three-pointed stones from Porto Rico. ${ }^{15}$ "This type," says Dr Fewkes, "includes those specimens that are destitute of face, head, or limbs, and without superficial ornamentation. To it belong some of the smallest known specimens, one of which is barely an inch in length." Not only do the St Croix and St Thomas examples have these characteristics, but the St Croix specimen possesses also to a high degree the other feature to which Dr Fewkes likewise calls attention, while the St Thomas example also has this, only not to such a marked extent. Dr Fewkes says: "One charac-

\section{A N D M O N G R A P S}




\begin{tabular}{|c|c|}
\hline 92 & VIRG I N ISLA N D S \\
\hline & $\begin{array}{l}\text { teristic feature can not be passed with- } \\
\text { out notice, as it seems to prove them iden- } \\
\text { tical in character with decorated three- } \\
\text { pointed stones, to which they closely } \\
\text { approximate in form. The apex of the } \\
\text { conical projection tips slightly forward, } \\
\text { or rather, when seen in profile, one side } \\
\text { is more curved than the other." The } \\
\text { St Croix specimen is well fashioned and } \\
\text { smoothly finished; the under side is con- } \\
\text { vex, as if designed to be fastened to an- } \\
\text { other object. The St Thomas example } \\
\text { has a flat under surface and either has } \\
\text { not been well finished or shows the effects } \\
\text { of weathering. } \\
\text { - } \\
\text { Fig. } 3 \text { r.-Coral stone pestle from Salt river, St Croix. } \\
\text { Various other artifacts made of coral } \\
\text { stone were found in both the St Thomas } \\
\text { and the St Croix middens. Four pestles } \\
\text { of this material were collected, of which }\end{array}$ \\
\hline I & I NDIAN NOTES \\
\hline
\end{tabular}




\section{S T O N E W O R K}

one is illustrated in fig. $3 \mathrm{I}$. This pestle, which is II in. in length, was found in the deposits at Salt river on St Croix. A small, flat, coral mortar was also found.

During his archeological work on St Croix, the writer was presented by $\mathrm{Mr}$ Hamilton Jackson, of Christiansted, with a collar-stone that was found on the island. This object, illustrated in fig. 32 , is $I 7 \frac{1}{2} \mathrm{in}$. in length and $I 1 / 2$ in. wide; it is of the slender type and is "rightshouldered," according to the classification suggested by the late Professor Mason, ${ }^{16}$ as the rounded knob or projection with which it is provided would be on the right side if the object were placed over the head. The St Croix specimen is devoid of incised decoration, such as circles, triangles, or parallel lines, with which most of the slender collars from Porto Rico are provided. A rounded projection with an encircling ridge below is plainly shown on the outer edge below the curved shoulder. The diameter becomes gradually larger directly below the projection until it merges into a large panel,

\section{A N D M O NOGRAPHS}




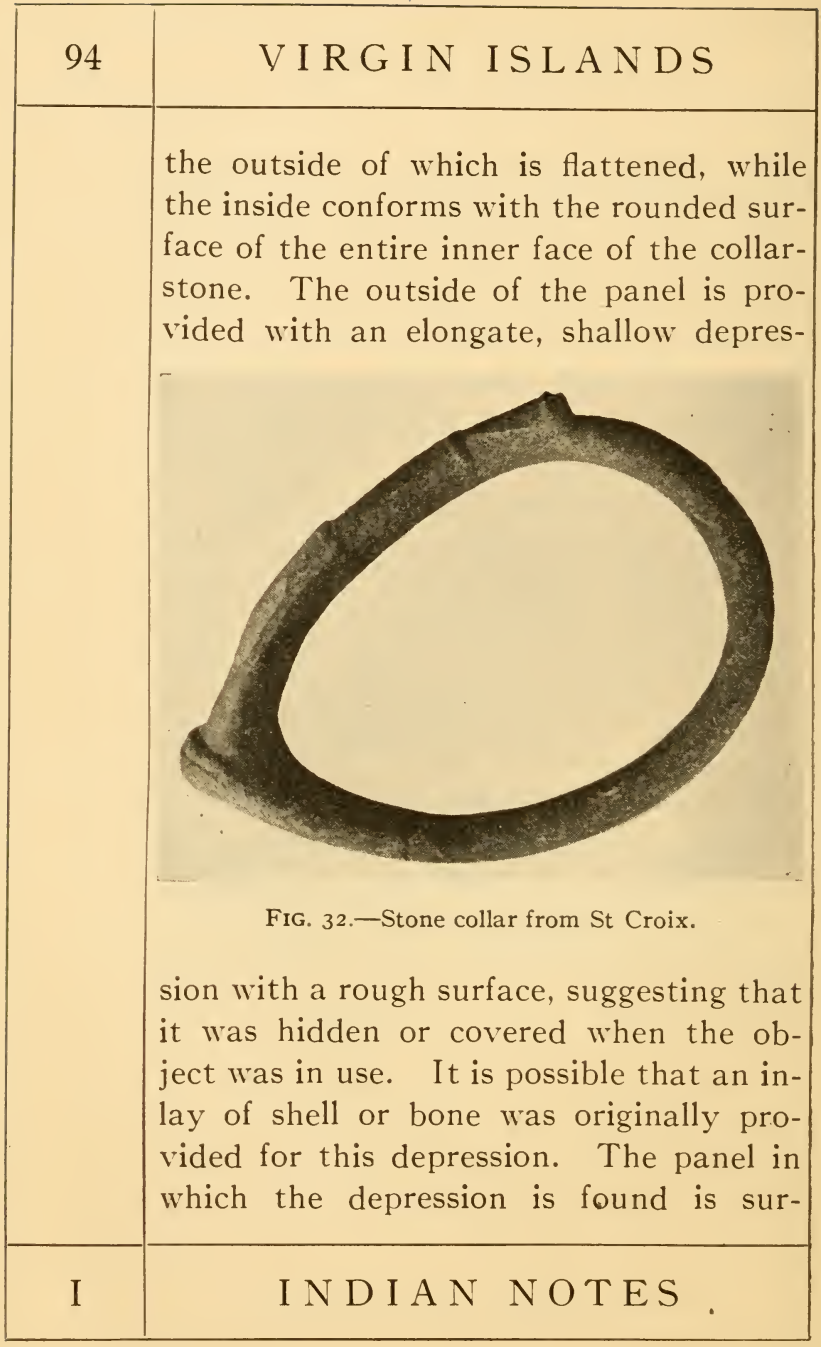




\begin{tabular}{l} 
B O N E O B J E C T S \\
\hline rounded by a slightly raised ridge, the \\
inner surface of which is marked by an \\
incised line; and another panel meets the \\
right-hand panel at a decided angle. \\
From the second panel, the end of which \\
is indistinctly indicated by a lightly- \\
raised encircling fillet, the shoulder of the \\
collar-stone emerges and retains an even, \\
circular form until it turns over and \\
reaches the rounded projection previously \\
described. The second panel has a rough \\
outer surface and is slightly rounded; \\
it overlaps the first panel at the junction \\
of the two and is rounded off at this \\
point, with an incised line to mark the \\
division more clearly. As in the case of \\
the potsherd illustrated in fig. 24, the \\
writer is of the opinion that this collar- \\
stone was not made on the island of St \\
Croix, but in some manner was acquired \\
from Porto Rico. \\
An the course of the excavations made \\
in the deposits at Magen's bay on St \\
Thomas, a swallow-stick-or "swallow- \\
\hline A D O N O G R A P H S
\end{tabular}




\begin{tabular}{|c|c|}
\hline 96 & VIR G I N I L A N D S \\
\hline & $\begin{array}{l}\text { ing stick," as it is usually called-was } \\
\text { found at a depth of about five feet. } \\
\text { This object, illustrated in pl. Ix, is } 81 / 4 \\
\text { in. long, and is typical of the culture-area } \\
\text { of Porto Rico and Santo Domingo. Un- } \\
\text { til the investigations on St Thomas were } \\
\text { conducted, no similar specimen had been } \\
\text { found, excepting on the two islands men- } \\
\text { tioned. The object is slightly curved } \\
\text { and flat at the rear, while the outer edge } \\
\text { is rounded. The handle represents an } \\
\text { extended human figure whose legs taper } \\
\text { into the shaft of the stick itself. The } \\
\text { arms are folded over the abdomen, with } \\
\text { the fingers indicated by incised lines. } \\
\text { Between the elbow and the body is } \\
\text { found a perforation for the suspension of } \\
\text { the object by means of a cord. The } \\
\text { head is exceptionally well carved and } \\
\text { has perforated ears, from which perhaps } \\
\text { originally small shells were pendent. } \\
\text { The eyes are represented by two oval } \\
\text { shells, with round perforations, sunk into } \\
\text { the bone from which the swallow-stick is } \\
\text { made and are probably fastened with } \\
\text { resinous gum. The nose is well modeled }\end{array}$ \\
\hline I & I N D I A NOTES \\
\hline
\end{tabular}



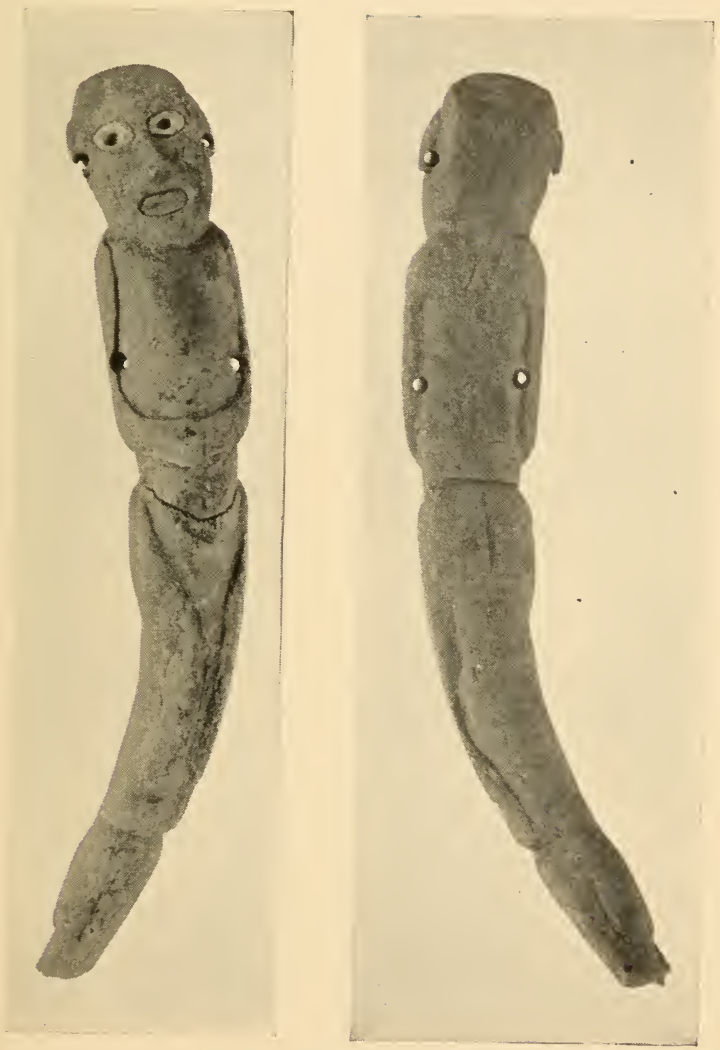

TWO VIEWS OF A SWALLOW-STICK OF BONE, FROM MAGEN'S BAY, ST THOMAS 



\section{B ONE OBJECTS}

in relief. The mouth is represented by an inset of mother-of-pearl upon which incised lines indicate the teeth. The "stick" itself is made from a rib of the manati, or seacow, the natural curve of which is followed.

According to Gomara, Román Pane, and other early historians, objects of this character were used by the priests in their ceremonies. ${ }^{17}$ The sticks were introduced into the throat to promote vomiting, it being the belief that it was necessary for the bodies of the priests to be purged before holding communion with the deities. Only one other bone swallow-stick from the West Indies is known to exist; it was collected by the late Archbishop Meriño of Santo Domingo on the island of Santo Domingo, and is now in the National Museum at Washington, where also may be seen three wooden swallow-sticks from the vicinity of Puerto Plata, Santo Domingo. The writer knows also of an object of this kind found in Porto Rico, made from the lip of a conch. The St Thomas specimen was

\section{A N D M ONOGRAPHS}




\begin{tabular}{|c|c|}
\hline 98 & VIRGIN ISLANDS \\
\hline & 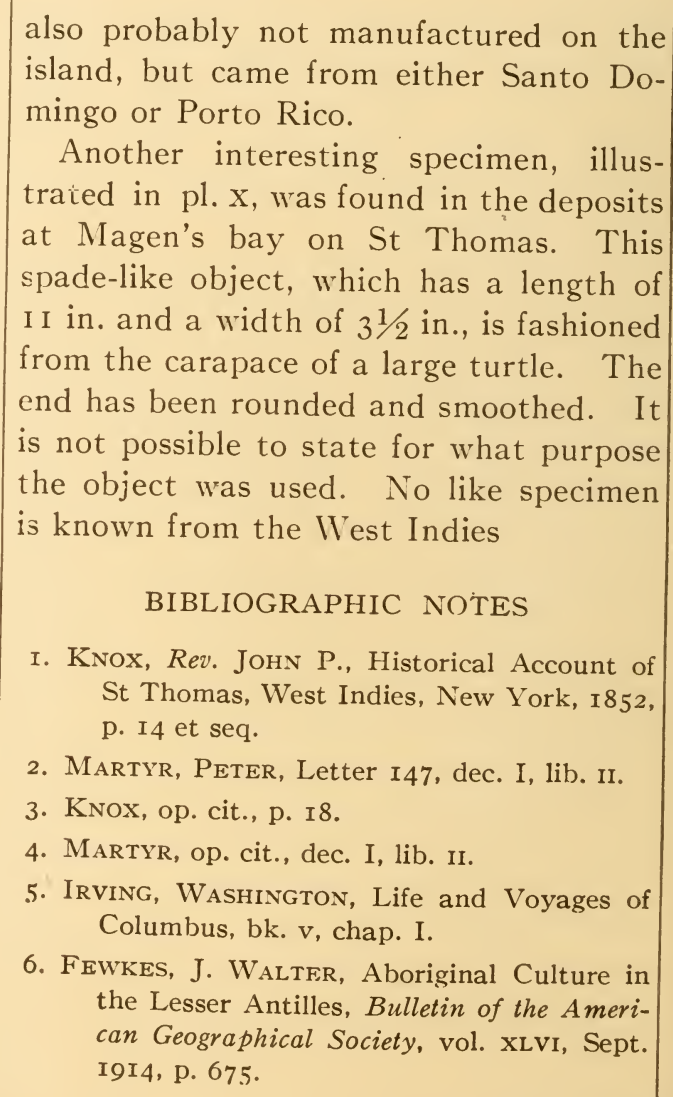 \\
\hline I & I N I A N NOTES \\
\hline
\end{tabular}




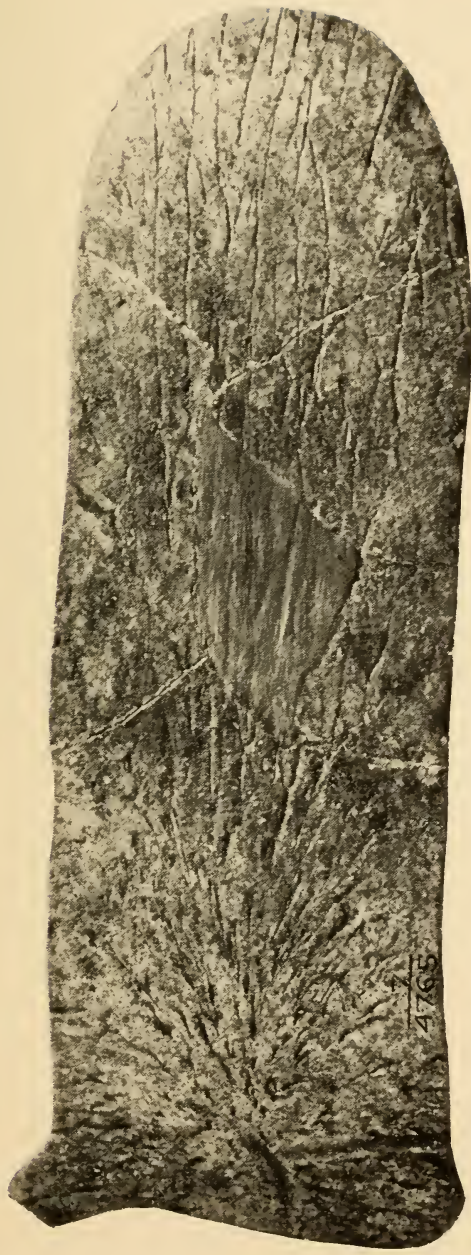

BONE OBJECT FROM MAGEN'S BAY, ST THOMAS 



\section{NOTES}

7. DE Booy, Theodoor, Certain Kitchen-middens in Jamaica, Amer. Anthropologist, n.s., vol. xv, no. 3, July-Sept. I9I3, p. 429, fig. II4. Reprinted as Contributions from the Museum of the American Indian, Heye Foundation, vol. I, no. 3, I9I3.

8. Miller, Gerrit S., Jr., Mammals and Reptiles Collected by Theodoor de Booy in the Virgin Islands, Proceedings U. S. National Museum, vol. Lrv, pl. 8I, Washington, I9I8.

9. Wetmore, Alexander, Bones of Birds Collected by Theodoor de Booy from Kitchenmidden Deposits in the Islands of St. Thomas and St. Croix, Proceedings U.S. National Museum, vol. LIV, pp. 5I3-522, pl. 82, Washington, I9I8.

ro. Fewkes, op. cit., p. 673 .

I. Op. cit.

I2. Op. cit.

13. DE Booy, Theodoor, Certain Archeological Investigations in Trinidad, British West Indies, Amer. Anthropologist, n.s., vol. xIx, no. 4 , pl. viii, $a . b, c$, Oct.-Dec. I9I7. Reprinted as Contributions from the Museum of the American Indian, Heye Foundation, vol. IV, no. 2, I9I 7 .

I4. DE Booy, Theodoor, Certain Kitchen-middens in Jamaica, op. cit., p. 434. DE Booy, THEODOoR, Pottery from Certain

\section{A ND MONOGRAPHS}




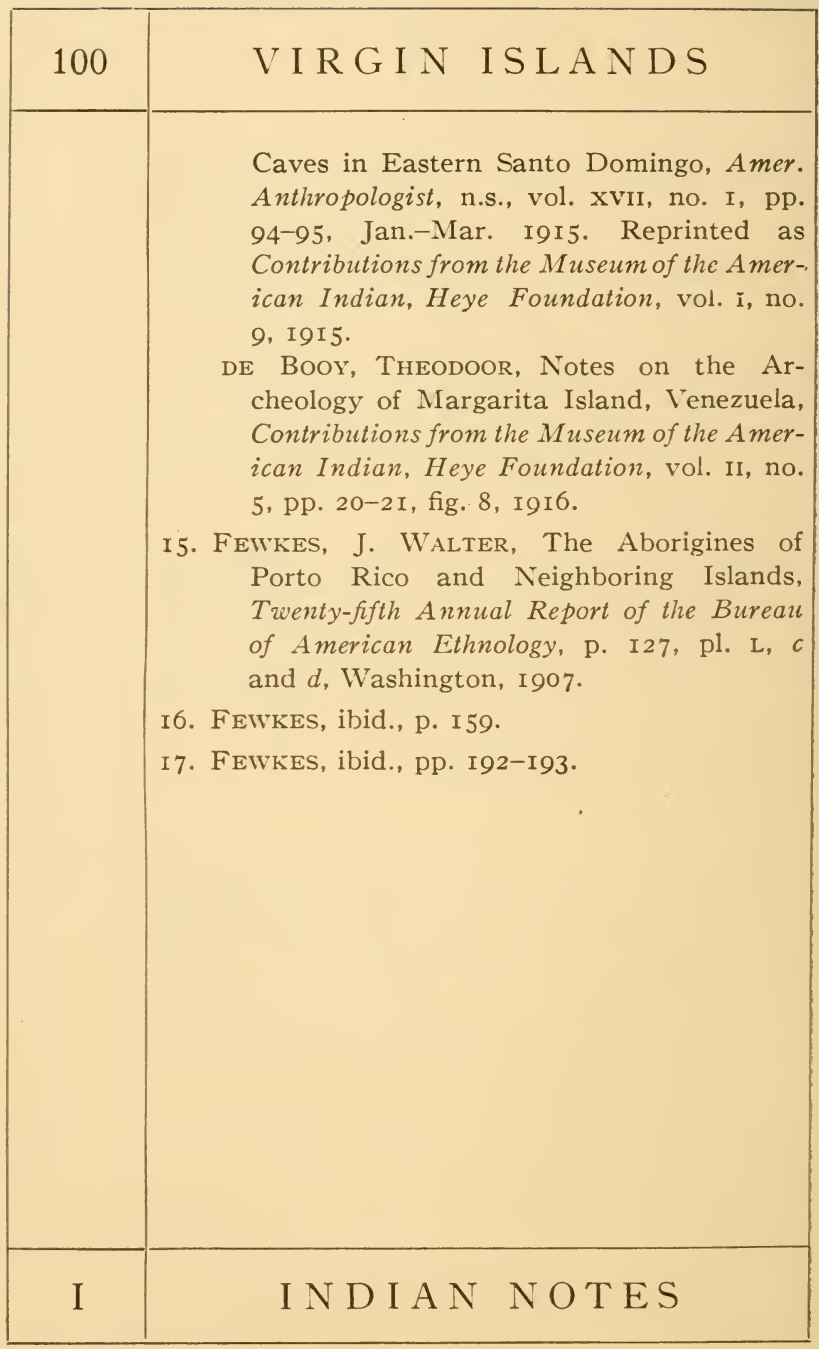


No. 5: Note on the Archeology of Chiriqui. By George Grant MacCurdy. Reprinted from Amer. Anthropol., Vol. 15, I9I3, No. 4. 5 oc.

No. 6: Petroglyphs of Saint Vincent, British West Indies. By Thomas Huckerby. Reprinted from Amer. Anthropol., Vol. I6, 19I4. No. 2. 5oc.

No. 7: Prehistoric Objects from a Shell-heap at Erin Bay, Trinidad. By J. Walter Fewkes. Reprinted from Amer. Anthropol., Vol. I6, I9I4, No. 2. $50 \mathrm{O}$.

No. 8: Relations of Aboriginal Culture and Environment in the Lesser Antilles. By J. Walter Fewkes. Reprinted from Bull. Amer. Geogr. Soc., Vol. 46, I9I4, No. 9. 50c.

No. 9: Pottery from Certain Caves in Eastern Santo Domingo, West Indies. By Theodoor de Booy. Reprinted from Amer. Anthropol., Vol. I7, I9I5, No. I. 50c.

\section{Vol. 2}

No. I: Exploration of a Munsee Cemetery near Montague, New Jersey. By George G. Heye and George H. Pepper. 19I5. \$1.00.

No. 2: Engraved Celts from the Antilles. By J. Walter Fewkes. 1915. 50c.

No. 3: Certain West Indian Superstitions Pertaining to Celts. By Theodoor de Booy. Reprinted from Journ. Amer. Folk-Lore, Vol. 28, No. I07, I9I5. $50 \mathrm{c}$.

No. 4: The Nanticoke Community of Delaware. By Frank G. Speck. I9I5. \$I.0o.

No. 5: Notes on the Archeology of Margarita Island, Venezuela. By Theodoor de Booy. 19I6. $50 \mathrm{c}$.

No. 6: Monolithic Axes and Their Distribution in Ancient America. By Marshall H. Saville. I9I6. 50c. 
SMITHSONIAN INSTITUTION LIBRARIES

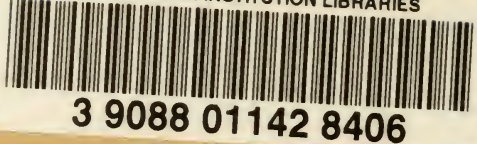

Vol. 3

Physical Anthropology of the Lenape or Delawares, and of the Eastern Indians in General. By Aleš Hrdlička. (Bur. of Amer. Ethnol., Bull. 62, 1916, with added title-page and cover.) \$I.0o.

\section{Vol. 4}

No. I: The Technique of Porcupine-Quill Decoration among the North American Indians. By William C. Orchard. I9I6. \$I.oo.

No. 2: Certain Archeological Investigations in Trinidad, British West Indies. By Theodoor de Booy. Reprinted from Amer. Anthropol., Vol. 19, I917, No. 4. 50c.

No. 3: The Nacoochee Mound in Georgia. By George G. Heye, F. W. Hodge, and George H. Pepper. I9I8. \$I.50.

\section{Vol. 5}

No. I: A Letter of Pedro de Alvarado Relating to His Expedition to Ecuador [1534]. By Marshall H. Saville. I9I7. 50c.

No. 2: The Diegueño Ceremony of the DeathImages. By E. H. Davis. I9I9. 5oc.

No. 3: Certain Mounds in Haywood County, North Carolina. By George G. Heye. Reprinted from Holmes Anniversary Volume, I9I6. I9I9. 50c.

No. 4: Exploration of Aboriginal Sites at Throgs Neck and Clasons Point, New York City. By Alanson Skinner. I919. \$1.00.

Address:

Museum of the American Indian, Heye Foundation, BROADWAY AT I55TH ST., NEW YORK CitY. 